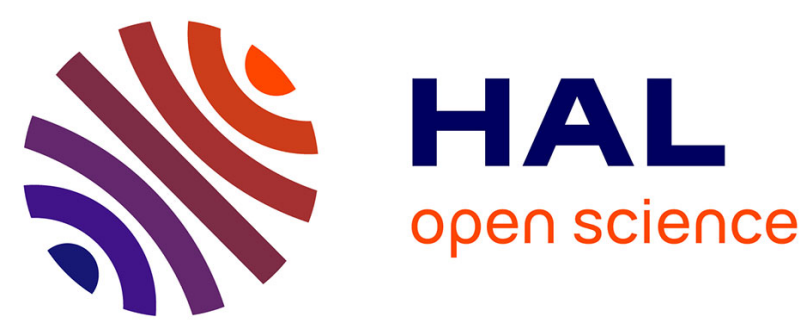

\title{
MOSAICA: A multi-scale bioeconomic model for the design and ex ante assessment of cropping system mosaics
}

Pierre Chopin, Loic Guinde, Jean-Marc Blazy, Thierry Doré

\section{- To cite this version:}

Pierre Chopin, Loic Guinde, Jean-Marc Blazy, Thierry Doré. MOSAICA: A multi-scale bioeconomic model for the design and ex ante assessment of cropping system mosaics. Agricultural Systems, 2015, 140, pp.26-39. 10.1016/j.agsy.2015.08.006 . hal-01216256

\section{HAL Id: hal-01216256 \\ https://hal.science/hal-01216256}

Submitted on 27 Sep 2019

HAL is a multi-disciplinary open access archive for the deposit and dissemination of scientific research documents, whether they are published or not. The documents may come from teaching and research institutions in France or abroad, or from public or private research centers.
L'archive ouverte pluridisciplinaire HAL, est destinée au dépôt et à la diffusion de documents scientifiques de niveau recherche, publiés ou non, émanant des établissements d'enseignement et de recherche français ou étrangers, des laboratoires publics ou privés. 
Doi : 10.1016/j.agsy.2015.08.006

Chopin, P., Blazy, J-M., Guindé, L., Doré, T., 2015. MOSAICA: A multi-scale bioeconomic model for the design and ex ante assessment of cropping system mosaics. Agricultural systems 140, 26-39.

Title: MOSAICA: A multi-scale bioeconomic model for the design and ex ante assessment of cropping system mosaics

Authors name: Pierre Chopin ${ }^{* a}$, Thierry Doré ${ }^{\text {b,c }}$, Loïc Guindé a Jean-Marc Blazy a

e-mail of the corresponding author: pierre.chopin@antilles.inra.fr

\section{Affiliations:}

${ }^{a}$ INRA, UR1321 ASTRO Agrosystèmes tropicaux, F-97170 Petit-Bourg (Guadeloupe), France

${ }^{\mathrm{b}}$ AgroParisTech, UMR 211 Agronomie, F-78850 Thiverval-Grignon, France

c INRA, UMR 211 Agronomie, F-78850 Thiverval-Grignon, France

\section{Abstract}

To understand the effects of policy changes on organisations and compositions of cropping systems at regional scale and their contribution to the sustainable development of regions, we built a regional, spatially explicit, multi-scale, bioeconomic model called MOSAICA. This model explicitly incorporates information at field, farm, sub-regional and regional scale to provide cropping system mosaics by way of regional optimisation of the sum of individual farmer's utilities under field, farm and territory biophysical and socio-economic constraints. Its generic structure means it can be used in different regions with geographic information on the location of the field and farm, data on cropping system performance, on location factors and on policy schemes. We used the model in Guadeloupe to test the impact of three scenarios of change on the agricultural subsidy regimes. The model produced three cropping system mosaics which reduced the area under banana and sugarcane, turned specialized 
banana and sugarcane farming systems into breeding systems while improving the overall contribution of agriculture to sustainable development. The spatially explicit results of changes in ecosystem services, and in farming systems with MOSAICA make it an appropriate decision-aid tool for regional planning.

\section{Highlights}

- We built a multi-scale spatially explicit regional bioeconomic model called MOSAICA

- MOSAICA combines field, farm, and regional data to produce cropping system mosaics

- MOSAICA models impacts of policy and novel scenarios on cropping systems mosaics

- Spatially explicit indicators can help decision-makers to assess different targeted policies

- MOSAICA can help explore scenarios to improve sustainable development of regions

Keywords: land use change; scenarios; ecosystem services; sustainability indicators; farm typology; agricultural landscapes

\section{Introduction}

Agriculture plays an active role in the provision of ecosystem services by way of ecosystem management. Recent studies have shown that the spatial organisation of cropping systems, which are called cropping system mosaics at the landscape scale, drives the provision of some ecosystem services (Thenail et al., 2011). These cropping system mosaics contribute to the protection of soils (Ronfort et al., 2011), the rational use of water (Bergez et al., 2007) and the conservation of biodiversity (Rusch et al., 2012), among others. The cropping system mosaic is also important for the provision of economic and social services, such as the provision of food and employment. Cropping system mosaics are the results of farmer cropping system choices at the field level (Dury et al., 2011). 
A cropping system choice is driven by a range of parameters that act at the field, farm and regional scale (Aubry et al., 1998). Biophysical drivers (e.g., the slope, the rainfall), social factors (e.g., the age of the farmer), economic factors (e.g., the investment capacity), farm structure and resources (e.g., the farm size, the number of workers), the farmer's objective and risk aversion can strongly drive the choice of cropping system. At the field scale, biophysical factors can constrain the adoption of new cropping systems (Chopin and Blazy, 2013), and the change in the production quota at the farm scale and the personal objectives of farmers affect the choice of farming systems (Bureau et al., 2001). At the regional scale, the implementation of agricultural policies (Flichman et al., 2011) and protected environmental areas drive the choice of crops and agricultural practices. Some of these factors are spatially heterogeneous and can then affect farmer choices in a different way depending on their location in the territory. The location of cropping systems has a direct impact on the values of ecosystem services that are provided by agriculture. Thus, to manage ecosystem service provision at the regional scale, decision-makers should implement well-adapted, multi-scale, spatially explicit policies aimed at organising the landscape to increase the provision of services in the desired direction.

Bioeconomic models have been frequently used for ex ante assessments of impacts from policy changes on the choice of farmer cropping systems at the farm scale. This type of model links farmer resources and context variables with activities that describe cropping systems (Flichman et al., 2002; Janssen and van Ittersum, 2007). These systems have been widely used in a range of different studies primarily at the farm scale (Dogliotti et al, 2005; Louhichi et al., 2010; Belhouchette et al., 2011; Leite et al., 2014) or from the farm scale to the regional scale (Laborte et al., 2007; van Ittersum et al., 2008).

However, the interrelationships between the field, farm and regional scales have scarcely been explicitly integrated into bioeconomic models despite their influence on the decision-making process of farmers (Delmotte et al., 2013). Moreover, assessing the consequences of cropping system changes 
in current bioeconomic models is not spatially explicit, which decreases the usefulness of the assessment for decision-makers, who want to determine the impact of the policy on the cropping system mosaics and the evolution of the contribution from these mosaics to the sustainable development of their region. Some regional models including SOLUS (Schipper et al., 1998) and Landscape IMAGES (Groot et al., 2007) take different spatial scales into account in the design and assessment of policy support for sustainable land-use options. However, SOLUS does not directly account for individual constraints at farm level (Schipper et al., 1998) and IMAGES is mostly used to optimise landscape functions to explore possible trade-offs among these functions with an evolutionary algorithm.

To assess the effects of policies on the contribution of cropping systems to sustainable development at a regional scale, we built a regional, spatially explicit, multi-scale bioeconomic model of farmers' choice of cropping systems at the field scale. The economic component is embedded in the decision model, which is based on the optimisation of the overall gross margin with a risk coefficient under farm resources constraints such as farm size or workforce. The biophysical part of MOSAICA relies on (i) an algorithm of cropping system allocation, which is under the conjoint influence of the biophysical context of the fields and the biophysical performance of the cropping systems, and (ii) the biophysical process behind the equations used to calculate the indicators, which provide information on the pressure of the cropping system mosaic on the ecosystems. This model can optimise the allocation of cropping systems regionally at the field scale by accounting for the constraints and opportunities at the field level, the availability of production factors at the farm scale, farmers' attitudes to risk, the policy implemented and the availability of resources (e.g., water for irrigation) at the regional scale.

We first present the area of implementation and then the bioeconomic model for a scenario analysis at the regional scale with an application in Guadeloupe, a French Outermost Region, with three scenarios. 


\subsection{Area of implementation}

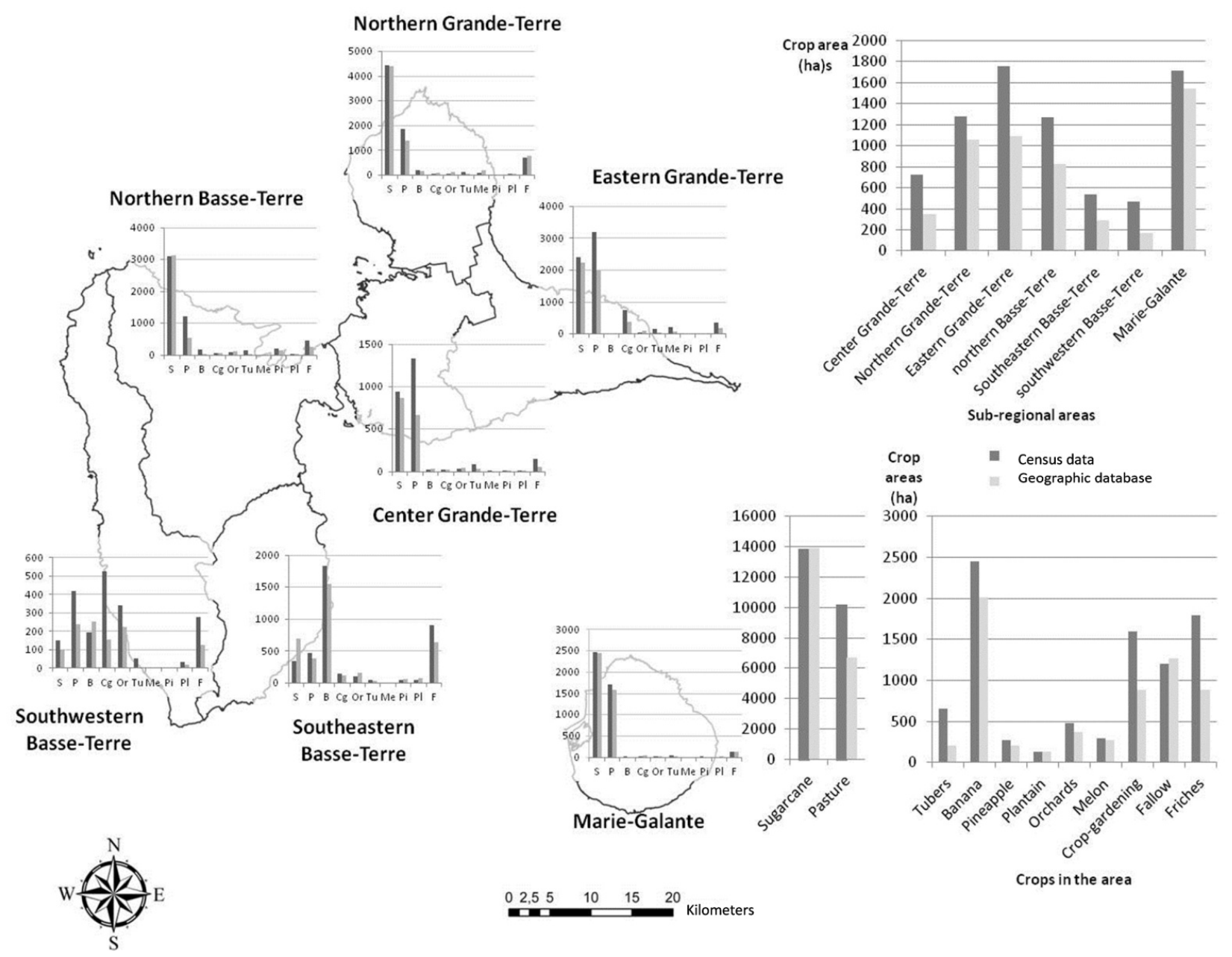

Figure 1: Crop organisation at the district scale and comparison of the census data in 2010 with the geographic database used in the study. On the map, S stands for sugarcane, $\mathrm{P}$ for pasture, B for banana, $\mathrm{Cg}$ for crop-gardening, Or for orchards, Tu for tubers, Me for melon, Pi for pineapple, Pl for plantain and $\mathrm{F}$ for fallow

We implemented our generic bioeconomic model in Guadeloupe as an example. Guadeloupe is a French archipelago located in the Caribbean. In this area, the climate is tropical, rainfall is positively

111 correlated with relief, and ranges from 1,000 to 5,000 $\mathrm{mm} \mathrm{yr}^{-1}$. Soils in the mountain areas are acid,

112 Andosols, Nitosols, Ferralsols and vertic soils, while flat lands have Calcisols and Vertisols. The total 
114 Galante islands, is 32,948 hectares (PDRG, 2011), the different cropped areas and their spatial

115 arrangement within the territory, is shown in Figure 1.There are 7749 farms in Guadeloupe, and their

116 sizes range from less than one hectare to more than one hundred hectares, with an average of four

117 hectares (Agreste, 2010). This variability in the socioeconomic and biophysical context and farm

118 resources is responsible for the variability of the cropping systems, described through typologies such

119 as that of Blazy et al. (2009) for banana farms and Chopin et al. (2015) for farming systems.

\subsection{Overview of the bioeconomic model MOSAICA}

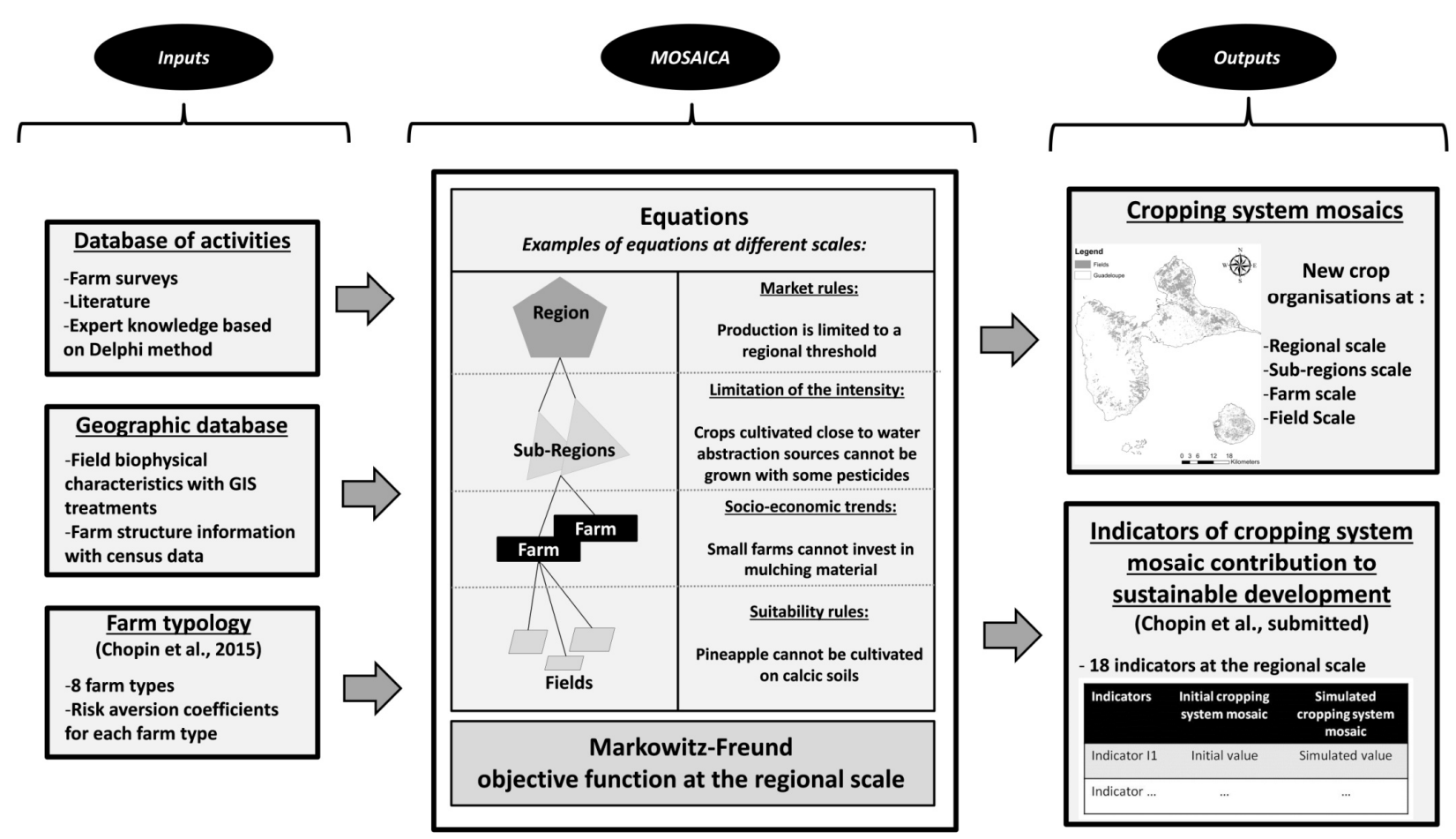

Figure 2: Presentation of Multi-scale model of the crOpping Systems Arrangement and Its

Contribution to sustAinable development (MOSAICA)

The modelling framework with the inputs and outputs of the Multi-scale model of the crOpping

Figure 2. The inputs of the model are i) the geographic database of fields that contain information

127 about the biophysical context and the farm structure, e.g., the farm size and the land tenure, ii) the

128 database of activities that describe the cropping systems and technical-economic coefficients that can 
be allocated to fields and iii) the farm typology and the classification algorithm for the eight farm types. The model optimizes the sum of individual farmer's utilities at the regional scale, which includes expected farm revenue and the risk aversion towards price and yield variations. The allocation of cropping systems is modelled through a set of equations that model the choice of cropping systems by farmers at different scales, namely the field, farm, sub-regional and regional scales. Optimisation is performed at the regional scale because equations are implemented at this scale to constrain the overall quantity of production for some crops within the entire area of study (because of market sizes or production quotas). The outputs of the model are the cropping system mosaics and the calculation of a range of sustainability indicators.

\subsection{Model inputs}

\subsubsection{Building the geographic databases}

First, a geographic database of fields is needed to calibrate the model and to design and assess cropping system mosaics. Second, a shapefile of farms is built with the information obtained on the farm locations. Third, the reliability of these databases must be checked before the scenario analysis at the regional scale, e.g., by comparison of the crop areas with regional public statistics. Fourth, the farm and field databases are completed with allocation factors that are biophysical and structural context variables.

In our case study in Guadeloupe, we worked with a geodatabase of fields that was provided by the local agency that helps farmers with their subsidy applications. The initial geographic database gathered 25057 fields, owned by 5336 farmers, and the crops grown on them in 2010 . The reliability of the farm and field databases is checked by comparing the area of each crop in the database with the agricultural census data in 2010 (Agreste, 2010). We can see that the total number of farms in the database is smaller than the actual number, 5336 farms compared with the initial 7749 farms, from the statistics. This discrepancy in the database is quite homogeneously spread among the sub-regional areas, but the Marie-Galante area is better represented than the eastern Grande-Terre and the 
southwestern Basse-Terre. The crop areas follow trends that are linked to the number of farms. Except for the lack of data on crop-gardening and pastures, a gap that prevents us from generalising some of the trends in changes observed in these crops (Figure 1), the database is satisfactory because it represents $80 \%$ of the agricultural area.

The field areas were then calculated and aggregated to obtain the size of each farm. Rainfall quantities were calculated based on the mean rainfall levels for 30 years. Inter-annual rainfall was assessed based on monthly rainfall determined from data from meteorological stations interpolated using the kriging tool in ArcGIS 9.3 (ESRI, 2009). The soil types were added based on an intersection with the soil shapefiles from a soil map (Colmet-Daage, 1969). In Guadeloupe, $20 \%$ of the fields are contaminated by chlordecone (Cabidoche et al., 2009), which can be up taken by some crops. The contamination rate depends on the soil chlordecone content, plant anatomy and physical-chemical properties of the soil (Cabidoche and Lesueur-Jannoyer, 2012). Consumption of contaminated crops has been shown to have harmful effects on humans (Multigner et al., 2015). The risk map for chlordecone contents was used to generate the chlordecone risk in the plots (Tillieut and Cabidoche, 2006). Irrigation schemes were intersected with fields to provide information on access to irrigation. The altitude was calculated from a 15-metre digital elevation model (DEM). The slope raster was determined from this DEM by using the slope tool. The fields were spatially intersected with sub-regions and determined based on the similarity of their soil and climate conditions. This biophysical information is used in two ways: (1) as constraints for the allocation of an activity to fields (for example, when rainfall is insufficient and irrigation is impossible, the activity cannot be adopted) and (2) as input parameters for the calculation of certain indicators (mainly environmental indicators). 


\begin{tabular}{|c|c|c|c|c|c|c|}
\hline $\begin{array}{l}\text { Example of } \\
\text { cropping } \\
\text { systems/ } \\
\text { Examples of } \\
\text { technical } \\
\text { coefficients }\end{array}$ & $\begin{array}{l}\text { Intensive } \\
\text { banana } \\
\text { cropping } \\
\text { system } \\
\text { in plain }\end{array}$ & $\begin{array}{l}\text { Traditional } \\
\text { beef } \\
\text { production } \\
\text { on pasture }\end{array}$ & $\begin{array}{l}\text { Staked } \\
\text { yam } \\
\text { based } \\
\text { cropping } \\
\text { system }\end{array}$ & $\begin{array}{l}\text { Mechanized } \\
\text { sugarcane } \\
\text { in the } \\
\text { northern } \\
\text { Basse-Terre }\end{array}$ & $\begin{array}{l}\text { Plantain } \\
\text { cropping } \\
\text { system } \\
\text { in } \\
\text { Basse- } \\
\text { Terre }\end{array}$ & $\begin{array}{l}\text { Pineapple } \\
\text { cropping } \\
\text { system } \\
\text { with } \\
\text { plastic } \\
\text { mulch }\end{array}$ \\
\hline $\begin{array}{l}\text { Mean yield } \\
\text { (tons.ha-1 } \cdot \mathrm{yr}^{-1} \text { ) }\end{array}$ & 44 & 0.66 & 15 & 74 & 26 & 23.3 \\
\hline $\begin{array}{l}\text { Price of sell } \\
\left(€ . \mathrm{t}^{-1}\right)\end{array}$ & 540 & 5400 & 2000 & 11.2 & 800 & 1100 \\
\hline $\begin{array}{l}\text { Income } \\
\left(€ \cdot \mathrm{ha}^{-1} \cdot \mathrm{yr}^{-1}\right)\end{array}$ & 42957 & 3564 & 30000 & 4852 & 20800 & 38500 \\
\hline $\begin{array}{l}\text { Mean variable } \\
\text { costs } \\
\left(€ \cdot \mathrm{ha}^{-1} \cdot \mathrm{yr}^{-1}\right)\end{array}$ & 32540 & 1974 & 20939 & 2212 & 9414 & 9303 \\
\hline $\begin{array}{l}\text { Gross margin } \\
\left(€ \cdot \mathrm{ha}^{-1} \cdot \mathrm{yr}^{-1}\right)\end{array}$ & 10417 & 1590 & 9061 & 2640 & 11386 & 16327 \\
\hline $\begin{array}{l}\text { Use of pesticides } \\
\text { (number of } \\
\text { doses. } \mathrm{yr}^{-1} \cdot \mathrm{ha}^{-1} \text { ) }\end{array}$ & 8 & 0 & 2 & 1 & 3 & 10 \\
\hline $\begin{array}{l}\text { Workforce needs } \\
\left(\text { hours. } \mathrm{ha}^{-1} \cdot \mathrm{yr}^{-1}\right)\end{array}$ & 1560 & 70 & 990 & 15 & 620 & 450 \\
\hline
\end{tabular}

The central element of the bioeconomic modelling approach is the simulated production process inputs needed to produce different outputs. The description of the cropping systems depends on the nature of data required for the optimisation process and on the calculation of the indicators (e.g., the average gross margin, cost of production, yield, working demand, sale price, etc.).

In our case study, we described 36 cropping systems currently used by farmers based on (i) previously published work, (ii) expert knowledge and (iii) on-farm surveys. The model is static and does not account for variations in cropping systems over time since its main aim is to perform a strategic

191 analysis of agricultural systems under new conditions in a what-if scenario framework. We then 192 describe multi-annual cropping system (such as banana, sugarcane or orchards), as an average of 193 practices and performances over the full life cycle of crops without a discount rate. The possible decrease in the gross margin of multi-annual cropping systems is taken into account in the positive and 
negative variations in the gross margin $\mathrm{Z}^{+}$and $\mathrm{Z}^{-}$defined for each activity a . Some of the activities with their technical coefficients are presented in Table 1. Livestock activities are included in pasture activities, which describe outputs from grazing livestock productions. Previously published works include scientific publications, such as Blazy et al. (2009) for banana production and technical guides published by local agricultural institutes and agricultural cooperatives. In total, 25 experts were first interviewed individually and then gathered together to come to an agreement on the characteristics of cropping systems by following the principle of the Delphi method (Harold and Murray, 2002). Ten further on-farm surveys were conducted to complete lacking data. Alternative activities could have been described but we chose not to do so in this study, since the aim of the scenarios was to assess the impacts of changes in the subsidies regime on existing farming systems. However with MOSAICA, it is possible to assess the potential contribution of new cropping systems to regional sustainability by defining new activities.

\subsubsection{Farm typology}

Statistical analyses were performed on the farm database to cluster farmers based on their decision processes.. Because crop acreages are the results of the farmer decision process (Aubry et al., 1998; Dury et al., 2011), these variables should be included in the statistical analysis, which may also include biophysical variables, farm structure or socio-economic variables (Andersen et al., 2007).

In our case study, we used a farming system typology and a classification algorithm that were realised on Guadeloupian farmers categorised into the following eight farm types: "arboriculturists", "banana growers", "specialised cane growers", "diversified cane growers", "diversified", "breeders", "cropgardeners" and "mixed cane growers-breeders"(Chopin et al., 2015). These are mainly the percentages of the acreages of the different crops grown on a given farm. As a cropping plan is the result of the farmer's decision process, the farm typology groups farms with similar decision processes. The classification algorithm, which consists of several thresholds of crop acreage proportions at the farm scale, has been implemented in our bioeconomic model as a set of if-then rules to provide (i) a 
classification of farm types at the initial state of the mosaic and (ii) a post-optimisation classification that shows the evolution of farming systems from the initial cropping system mosaic to the simulated one after scenario analysis.

\subsection{The model description}

\subsubsection{Objective function}

The objective function of our regional bioeconomic model is a Markowitz-Freund (Mosnier et al., 2009). The optimal acreage at the regional scale is the one obtained from the maximisation of utility $\mathbf{U}$, which is the maximum of the sum over the full population of farmers of the total gross margin $\boldsymbol{m}_{\boldsymbol{a}}$ of activity a balanced with the sum of expected positive and negative variations in the gross margin, respectively $\mathbf{Z}^{+}{ }_{\mathrm{a}}$ and $\mathbf{Z}_{\mathbf{a}}$, multiplied by a risk-aversion coefficient $\boldsymbol{\emptyset}$ at the farm scale (Equation 1 ). The risk is then modelled using a linear approach (Mosnier et al., 2009).

The coefficients of variability are determined for each activity based on agro-economic expertise and encompass both an agronomic risk (yield variability related to climate conditions, pest attacks or diseases) and commercial outlet risk (from the variability in the selling price across the selling season) aggregated together. We applied two variability coefficients $\mathbf{Z}^{+}{ }_{\mathbf{a}}$ and $\mathbf{Z}_{\mathbf{a}}$ (Equation 1 and 2 ) to each activity based on an appraisal of this risk because this type of risk formulation is known for generating good results in bioeconomic models (Arriaza et al., 2003). For instance, for sugarcane cropping systems in the northern part of Basse-Terre, these positive and negative variations have been set to respectively - $250 €$.ha.yr ${ }^{-1}$ and $+250 €$.ha.yr ${ }^{-1}$, because of its low commercial risk and low variability in the crop yield.

$$
M A X U=\sum_{f} \sum_{p} \sum_{a}\left[X_{a, p}\left(\bar{m}_{a}-\phi_{f}\left(Z_{a}^{+}+Z_{a}^{-}\right)\right]\right.
$$

$$
Z_{a}^{+}-Z_{a}^{-} \geq 0
$$

$$
\bar{m}_{a}=\left(\bar{Y}_{a} P_{a}+S_{a}\right)-C_{a}
$$


In Equation 3, $\mathbf{m}_{\mathbf{a}}$ is the average gross margin of activity $\mathbf{a}$ based on a mean yield $\mathbf{Y}$, a price $\mathbf{P}$ with subsidies $\mathbf{S}$ and a given level of variable cost $\mathbf{C}$ (Equation 3). The area of activity $\mathbf{a}$ is symbolised by $\mathbf{X}$, and $\mathbf{X}(\mathbf{a}, \mathbf{p})$ represents the vector of decision variables, that is to say, the area covered by each activity $\mathbf{a}$ (the cropping system in our case study) on plot $\mathbf{p}$ (Farms $\mathbf{f}$ can choose one or several cropping systems on the same plot).

\subsubsection{Constraint equations}

252

Equations are primarily implemented in bioeconomic models as constraints to the adoption of cropping systems by farmers. These equations impact the allocation process of cropping systems at 254 different scales. In our case study, we mixed expertise and descriptive statistics to highlight the thresholds of variables that described the locations of cropping systems (Leenhardt et al., 2010) and implemented them in several equations at different scales. The complete list of equations is given in the Appendix.

At the field scale, we implemented a set of equations linking the cropping systems to the slope, field area, rainfall amounts, altitude, soil type and land tenure, which were calculated for all individual fields and affect the choice of cropping systems. For instance, mechanised cropping systems were limited to a slope Slpmax of $15 \%$ because of the impossibility of ploughing or mechanically harvesting on steeper slopes in field $\mathbf{p}$ with a slope of Slp (Equation 4). 


\subsection{Calibration procedure}

\begin{tabular}{lc}
\hline Farm types & $\begin{array}{c}\text { Risk aversion } \\
\text { coefficient } \Phi\end{array}$ \\
\hline Arboriculturists & 1.3 \\
Banana growers & 1.2 \\
Specialised cane growers & 0.3 \\
Diversified cane growers & 1.4 \\
Diversified & 0.55 \\
Breeders & 2.4 \\
Crop-gardeners & 0 \\
Mixed cane growers - breeders & 2.3 \\
\hline
\end{tabular}
produced by activity a (respectively 4500 and 150 tons (Equation 6).

$\sum_{F} \sum_{p} \sum_{a}\left(X_{a, p} \bar{y}_{a}\right) \leq \sum_{f} \sum_{p} \sum_{a}\left(\right.$ Xinit $\left._{a, p} \bar{y}_{a}\right)+I_{a}$

At the sub-regional scale, environmentally and geographically protected indications constrain the adoption of cropping systems. At the regional scale, we defined the maximum thresholds for limiting the quantity of crops produced based on either production quotas for banana or sugar, respectively 77 977 and 10700 tons.yr ${ }^{-1}$ (PDRG, 2011; CTCS, 2005) or current consumption for non-exported crops, such as plantain, based on the sum of production for local market and importation $\mathbf{I}$ of the crop 
The calibration procedure is based on the allocation of several sets of risk aversion coefficients $\emptyset$ to farmers based on their farm type. These risk aversion coefficients at farm scale help reproduce farmer's cropping plans based on a hypothesis about their level of risk aversion. Several iterations are

$P A D(\%)=100 * \frac{\sum_{p}\left|\left(X_{\text {init }}(a)-X_{a}\right)\right|}{\sum_{p} X_{\text {init }}(a)}$ Because the purpose of our model is to ensure the correct prediction of the location of a cropping performed until $80 \%$ of farming systems are well-calibrated. After reaching this threshold, the model can be considered satisfactory.

In our case study, we tested several sets of risk aversion coefficients $\emptyset$ per farm type as calibrating coefficients of our model. The same risk aversion coefficient was allocated to each farm belonging to the same farm type (Table 2). We established a range of hypotheses on the level of risk aversion per farm type to start the calibration iteration. After running 100 iterations, we managed to obtain a set of risk aversion coefficients that provided satisfying results at the farm scale in terms of cultivated crop areas. The coefficient has a value that ranges from 0 , a risk neutral farm type, to crop-gardeners, approximately 3, a very risk-averse farm type, such as the breeders in this example (Acs et al., 2009).

\subsection{Evaluation of the model}

The base year outputs in a bioeconomic model should match those observed in reality. The percentage of absolute deviation (PAD) between the observed acreage $\boldsymbol{X i n i t}(\boldsymbol{a})$ for activity a and the simulated acreage $X(\boldsymbol{a})$ for a field $\boldsymbol{p}$, summed at a different spatial scale (i.e. at regional scale), is widely used to check this match (Hazell and Norton, 1986; Leite et al., 2014). The best calibration is reached when PAD is close to 0 .

\footnotetext{
system at various spatial scales, we checked the outputs of our model at multiple scales with this PAD
} 
(Equation 7). We considered the results to be satisfactory when the percentage of absolute deviation

311 (PAD) was less than 15\% for the primary crops at the regional scale, and 20\% in the sub-regions and

312 farms, as recommended by authors who assess the reliability of bioeconomic farm models

313 (Kanellopoulos et al., 2010; Hazell and Norton, 1986; Janssen and van Ittersum, 2007).

\subsection{Sustainability indicators at the regional scale}

315 The impact of agriculture on society at a regional scale depends on the state of the cropping system

316 mosaic. To assess these impacts, MOSAICA includes a set of sustainability indicators at the regional

317 scale. The indicators consist of a quantitative externality assessment of a farmer's choice of cropping

318 plan at the regional scale, and they are related to (i) the technical coefficients of farmers' cropping

319 systems allocated at the field scale, (ii) the location of fields in the region, which drives the potential

320 impacts of cropping systems on the response of agriculture to sustainability issues and (iii) the

321 properties of the fields (e.g., rainfall amount, the size of the field, etc.). The indicator score then varies

322 depending on the cropping systems allocated within the whole cropping system mosaic.

323 In our case study, one to three indicators were previously designed by Chopin et al. (submitted) for

324 each sustainability issue (Table 3). None of the economic indicators and few of the social indicators

325 are spatially explicit. They are determined based on the aggregated results of all individual fields at the

326 regional scale (e.g. the agricultural added value is the aggregation of the gross margins at field scale).

327 On the other hand, most environmental indicators account for the location of each cropping system.

328 More information on the indicators can be found in supplementary material. 


\begin{tabular}{|c|c|c|c|}
\hline Sustainability objectives & Indicators & Description & Units \\
\hline \multirow[b]{2}{*}{ Improving agricultural revenue } & Overall farm revenues & Aggregation of cropping system gross margins at regional scale & €.yr-1 \\
\hline & $\begin{array}{l}\text { Repartition of revenue among the farm } \\
\text { population }\end{array}$ & $\begin{array}{l}\text { The Gini indicator measures the balance of farm revenue repartition } \\
\text { (high value: inequity in repartition / low value: equity) (Ceriani and } \\
\text { Verme, 2012) }\end{array}$ & - \\
\hline $\begin{array}{l}\text { Increasing autonomy from } \\
\text { subsidies }\end{array}$ & Total amount of subsidies & Aggregation of cropping system subsidies at regional scale & $€ . \mathrm{yr}^{-1}$ \\
\hline \multirow{3}{*}{ Reaching food self-sufficiency } & Ratio of produced carbohydrates over needs & Aggregation of the entire production of carbohydrates, proteins and & $\%$ \\
\hline & Ratio of produced proteins over needs & fats from crop production at regional scale divided by the needs of & $\%$ \\
\hline & Ratio of produced fats over needs & $\begin{array}{l}\text { population calculated based on the local population size and } \\
\text { average needs }\end{array}$ & $\%$ \\
\hline $\begin{array}{l}\text { Producing local energy from } \\
\text { agriculture }\end{array}$ & Energy potential produced by crops & $\begin{array}{l}\text { Aggregation of cropping system potential production of energy at } \\
\text { regional scale }\end{array}$ & MW. $\mathrm{yr}^{-1}$ \\
\hline Contributing to employment & Total number of workers & $\begin{array}{l}\text { Aggregation of the number of workers needed for cropping systems } \\
\text { at regional scale }\end{array}$ & pers. $\mathrm{yr}^{-1}$ \\
\hline $\begin{array}{l}\text { Insuring safety of locally } \\
\text { produced foodstuff }\end{array}$ & $\begin{array}{l}\text { Area with a potential chlordecone } \\
\text { contamination of food crops }\end{array}$ & $\begin{array}{l}\text { Sum of the area for which contamination of crops is possible due to } \\
\text { the contamination of soil, the type of crop grown and the soil type }\end{array}$ & ha \\
\hline $\begin{array}{l}\text { Improving the state of } \\
\text { biodiversity }\end{array}$ & Risk for birds in high-value ecological zones & $\begin{array}{l}\text { Average score of pesticide risk in these areas due to cropping } \\
\text { system using pesticide with acute toxicity and the quantity of active } \\
\text { ingredients }\end{array}$ & - \\
\hline \multirow{4}{*}{ Enhancing water quality } & Ratio of potentially polluted rivers & Qualitative score determined at the field scale with a decision tree & $\%$ \\
\hline & $\begin{array}{l}\text { Ratio of potentially polluted water abstraction } \\
\text { sources }\end{array}$ & $\begin{array}{l}\text { with information on the quantity of active ingredients, the quantity } \\
\text { of run-off based on expert knowledge for each type of soil, the half- } \\
\text { life of the active ingredients in the environment, ... ( see Tixier et }\end{array}$ & $\%$ \\
\hline & Ratio of potentially polluted water catchments & $\begin{array}{l}\text { al, 2006). The score obtained at water body scale is the average } \\
\text { score from fields located around water bodies. The proportion of } \\
\text { water bodies potentially polluted are the ones with a score above } 7 \text {. }\end{array}$ & $\%$ \\
\hline & Amount of water needed for irrigation & $\begin{array}{l}\text { Aggregation of cropping system needs for water based on the } \\
\text { quantity of rainfalls and the average crop needs per month }\end{array}$ & $\mathrm{m}^{3}$ \\
\hline Protecting soil quality & Area potentially eroded due to farming practices & $\begin{array}{l}\text { Sum of field areas with a score above } 6 \text { obtained with a decision } \\
\text { tree based on the type of soil, the crop cover of activities... (Tixier, } \\
\text { 2005) }\end{array}$ & ha \\
\hline $\begin{array}{l}\text { Decreasing contribution to } \\
\text { climate change }\end{array}$ & Overall $\mathrm{CO}_{2}$ emissions from farming activities & $\begin{array}{l}\text { Aggregation of cropping system emissions from cradle to farm gate } \\
\text { with the exportation of crops }\end{array}$ & tons $\mathrm{CO}_{2} \cdot \mathrm{yr}^{-1}$ \\
\hline $\begin{array}{l}\text { Improving diversity of } \\
\text { agricultural landscapes }\end{array}$ & Diversity of crops across the landscape & $\begin{array}{l}\text { Simpson's diversity indicator: it assesses the diversity of crops } \\
\text { through the calculation of the proportion of each crop in the entire } \\
\text { agricultural area (Simpson, 1949) }\end{array}$ & - \\
\hline
\end{tabular}

Table 3: Indicators for the assessment of cropping system mosaics with MOSAICA 


\subsection{Policy scenarios}

331 The current policy and the scenarios developed to illustrate the use of MOSAICA are summarised in

332 Figure 3. The cropping system mosaic, which was obtained with the calibration procedure, is used as

333 the base year in the scenario analysis presented in the next sections.

\subsubsection{Current agricultural policy in Guadeloupe}

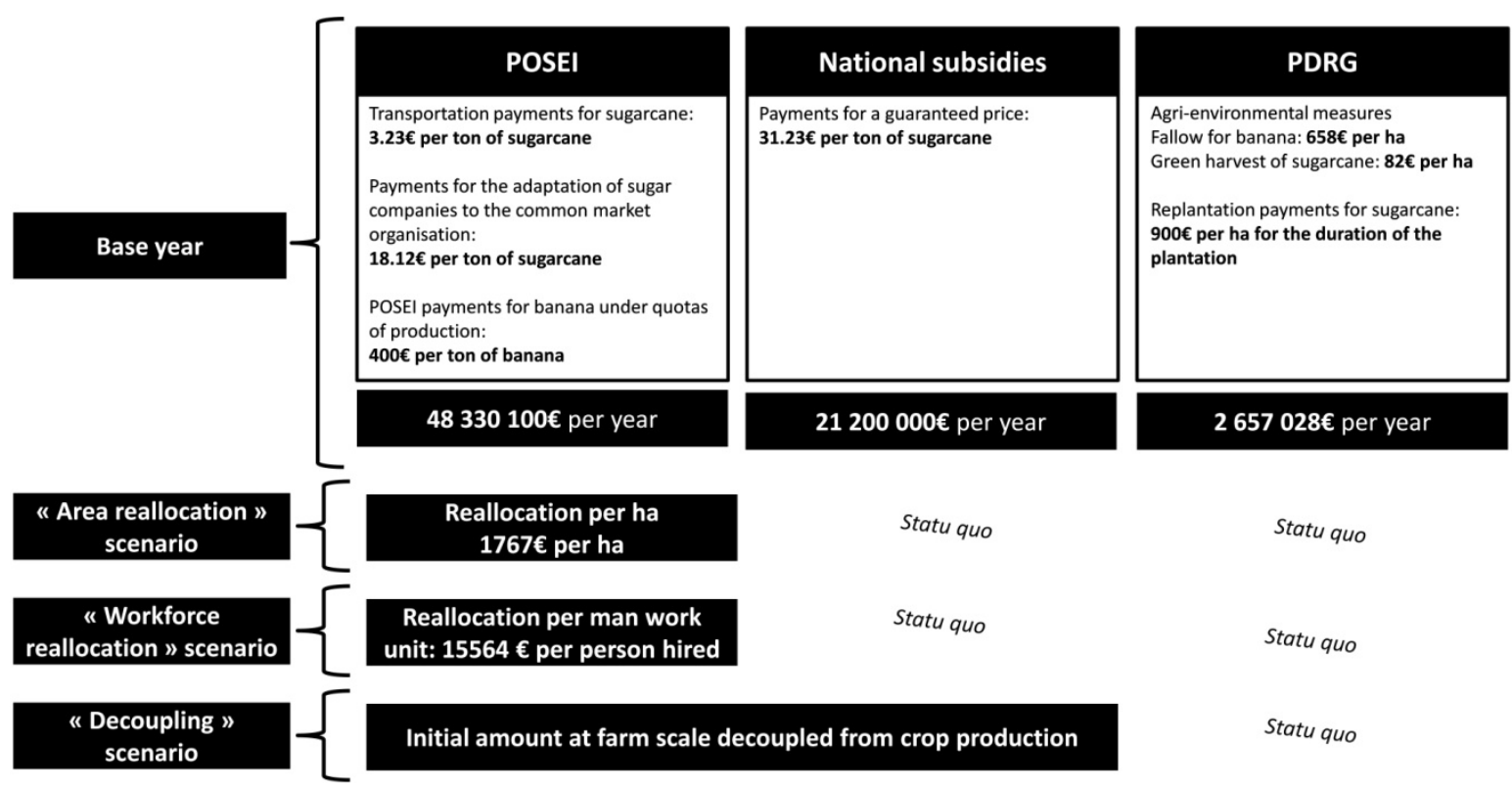

337 Figure 3: Description of the current agricultural policy in Guadeloupe and the changes tested in

338 scenarios

340 Currently, agriculture in Guadeloupe is highly subsidised by several agricultural policies. The primary

341 policies in favour of the Outermost Regions are i) the POSEI ("Program of specific options for

342 isolation and insularity") arrangements, ii) the rural development program of Guadeloupe 2007-2013

343 that encompass the less favoured area measures, the agri-environmental measures and the structural

344 measures to sectors and iii) national subsidies (Figure 3 - see Supplementary materials for more

345 details). 


\subsubsection{Expected changes in Guadeloupe's agricultural policy}

348 The current policy towards Outermost Regions is going to change because of the pressure from the

349 World Trade Organization to liberalise the sugarcane and banana markets (European Union, 2012)..

350 For sugar, national subsidies are going to disappear by 2017, and the banana contingent from the RUP

351 may disappear by 2020 . We will then test the impact of three scenarios in terms of changes in the

352 subsidy levels and characteristics of the cropping system mosaics at the regional scale and the effects

353 of these mosaics on the contribution of agriculture to the sustainable development of society.

354 In the "Area reallocation" scenario, the entire quantity of subsidies from the first pillar, or 48.34

355 M€.yr ${ }^{-1}$, is reallocated to each crop equally for $1768 €$ per hectare of production, including sugarcane

356 and bananas (Figure 3).

357 In the "Workforce reallocation" scenario, the amount of subsidies from the first pillar is reallocated,

358 for each unit of hired workforce with $15569 €$ per unit of workforce. The rationale behind distributing

359 subsidies according to the number of hired labourers is the fact that the unemployment rate is high in

360 Guadeloupe (27\%) and such subsidies could offer new opportunities for stimulating the labour market

361 (Figure 3).

362 In the "Decoupling" scenario, the current level of payments from national subsidies and POSEI

363 payments are defined at farm level, and represent 69.8 M€.yr ${ }^{-1}$, and they are maintained at farm level

364 but completely decoupled from agricultural production (Figure 3). Subsidies to agriculture are no

365 longer linked to crop production like in the CAP decoupling scheme in Europe (Viaggi et al., 2011).

366

367 3. Results

368

3.1. Model calibration

369

3.1.1. At the regional scale 


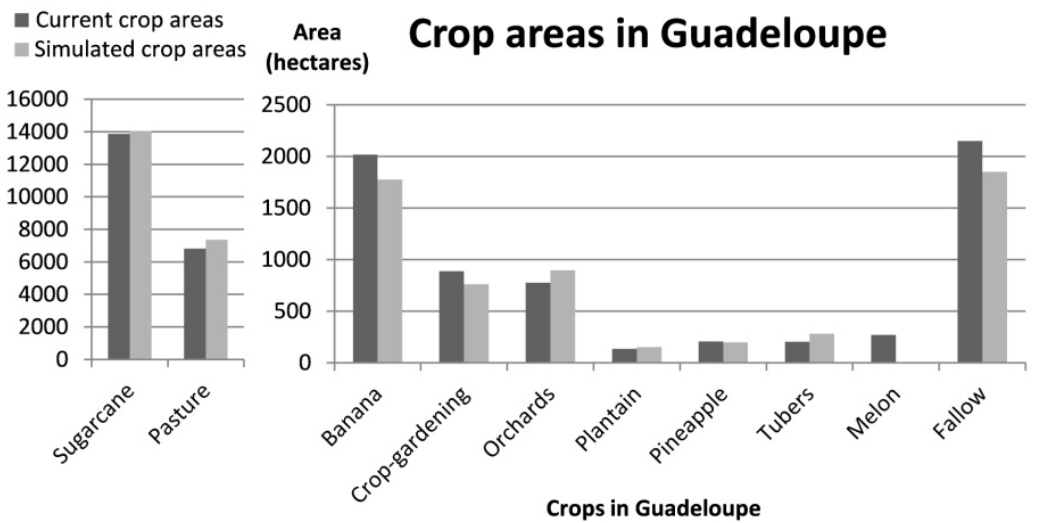

Crops in Guadeloupe

371 Figure 4: Comparison of the regional crop areas between the observed situation and the simulated one

372 after the calibration step

373

374 We first compared the simulated acreage allocated to different crops under the current policy with

375 those observed in Guadeloupe in the geographic database. The calibration procedure used in the

376 modelling framework resulted in a good match for 8 out of 10 agricultural uses over the territory

377 (Figure 4). Results for melons were not satisfactory with a PAD of 100\% because the melon cropping

378 system was not adopted by farmers because they rent out their land to a company which produces

379 melon for export and renting out land is not taken into account in the model. However, we show that,

380 at this scale, the model provides reliable information despite some deviations compared with the initial

381 state of the system for two minor crops. 


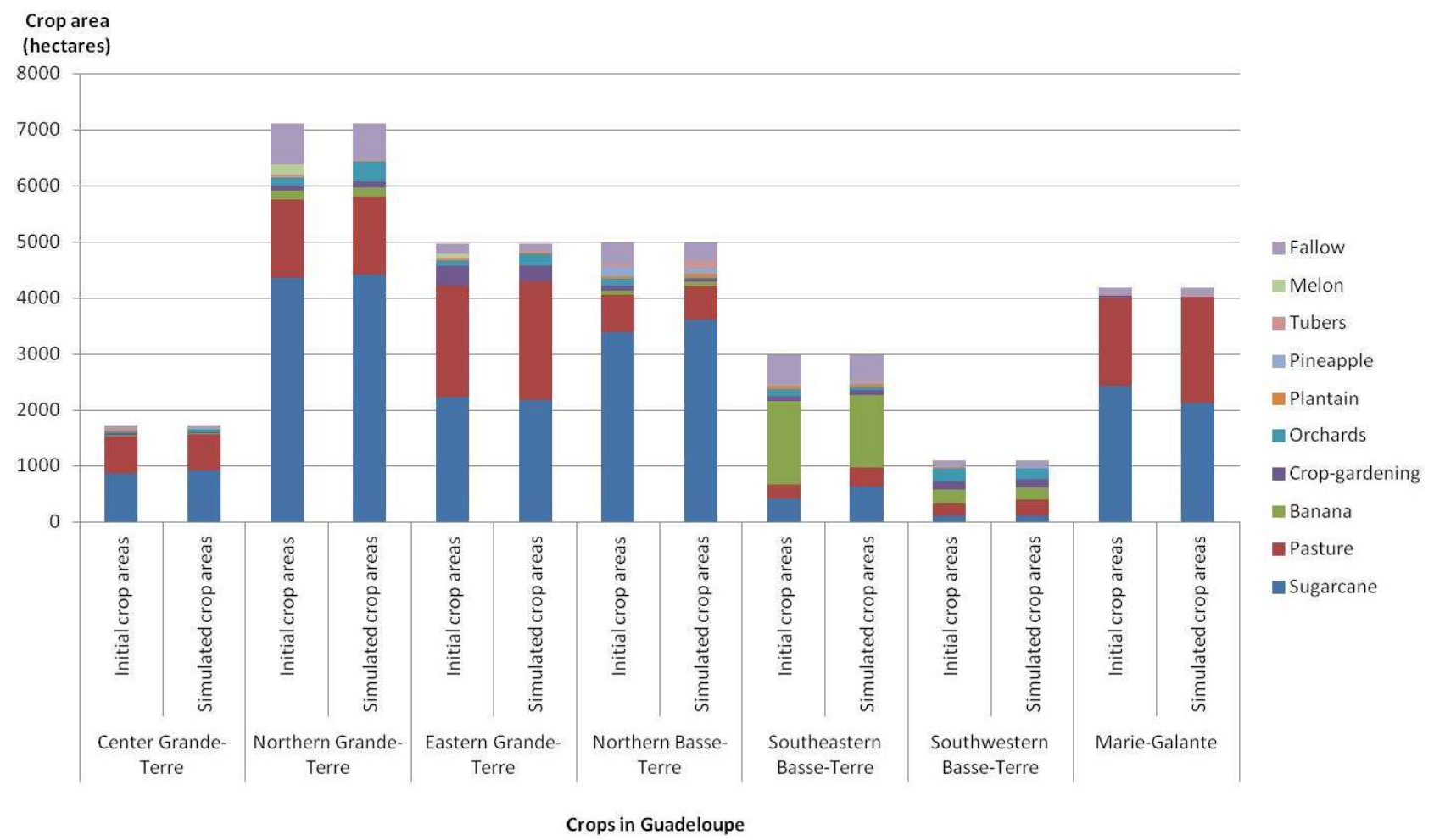

Figure 5: Comparison of the sub-regional crop areas between the observed situation and the simulated one after the calibration step

At the sub-regional scale, a comparison of the initial and simulated acreages reveals the predictive quality of the model (Figure 5). In Grande-Terre and Marie Galante, sugarcane and pastures were well simulated with, for instance, PAD values of $5 \%$ and $1 \%$, respectively, for the centre of Grande-Terre. Bananas are well represented in the north with a PAD of $1 \%$. For the east of Grande-Terre, the cropgardening level is quite underestimated but acceptable, with a PAD of 20\%. In Basse-Terre, the north is well-simulated for sugarcane, pasture and bananas. In the south-east, only the sugarcane level is underestimated because of a conflict in the simulation between sugarcane and fallow fields as adopted within a banana-based system for rotations. In the south-west, the simulation results are good for orchards, bananas, crop-gardening, sugarcane and fallow fields but less favourable for pasture with $28 \%$. We conclude from these results that the MOSAICA model accurately reproduces the agricultural landscape characteristics of the sub-regions in Guadeloupe. 


\begin{tabular}{|c|c|c|c|c|c|c|c|c|c|c|}
\hline $\begin{array}{l}\text { Number of farms in } \\
\text { types at regional scale } \\
\text { Initial } \backslash \text { simulated }\end{array}$ & $\begin{array}{l}\text { Arboricul } \\
\text { turists }\end{array}$ & $\begin{array}{l}\text { Banana } \\
\text { growers }\end{array}$ & $\begin{array}{l}\text { Specialised } \\
\text { cane } \\
\text { growers }\end{array}$ & $\begin{array}{c}\text { Diversified } \\
\text { cane growers }\end{array}$ & Diversified & Breeders & $\begin{array}{c}\text { Crop } \\
\text { gardeners }\end{array}$ & $\begin{array}{c}\text { Mixed } \\
\text { cane- } \\
\text { growers } \\
\text { breeders }\end{array}$ & $\begin{array}{l}\text { Total } \\
\text { (initial) }\end{array}$ & Matches \\
\hline Arboriculturists & 60 & 0 & 0 & 14 & 37 & 3 & 0 & 7 & 121 & $50 \%$ \\
\hline Banana growers & 2 & 159 & 0 & 7 & 15 & 3 & 0 & 19 & 205 & $78 \%$ \\
\hline Specialised cane growers & 0 & 0 & 1473 & 50 & 0 & 53 & 0 & 1 & 1577 & $93 \%$ \\
\hline Diversified cane growers & 14 & 0 & 257 & 665 & 24 & 71 & 0 & 19 & 1050 & $63 \%$ \\
\hline Diversified & 17 & 0 & 0 & 73 & 150 & 17 & 11 & 18 & 286 & $52 \%$ \\
\hline Breeders & 0 & 0 & 0 & 1 & 0 & 1072 & 0 & 16 & 1089 & $98 \%$ \\
\hline Crop gardeners & 0 & 0 & 0 & 0 & 13 & 0 & 141 & 0 & 154 & $92 \%$ \\
\hline $\begin{array}{l}\text { Mixed cane-growers } \\
\text { breeders }\end{array}$ & 0 & 1 & 0 & 35 & 1 & 235 & 0 & 582 & 854 & $68 \%$ \\
\hline Total (simulated) & 93 & 160 & 1730 & 845 & 240 & 1454 & 152 & 662 & 5336 & $81 \%$ \\
\hline
\end{tabular}

Table 4: Comparison of the number of types correctly modeled with the calibration procedure 


\subsubsection{At the farm scale}

401

402

403

404

405

406

407

408

409

410

411

412

413

414

415

416

\subsubsection{At the field scale}

\begin{tabular}{lccc}
\hline $\begin{array}{l}\text { Areas with homogeneous } \\
\text { soil and climate conditions }\end{array}$ & $\begin{array}{c}\text { Areas with a match between } \\
\text { the initial and simulated crop } \\
\text { (hectares) }\end{array}$ & $\begin{array}{c}\text { Total area } \\
\text { (hectares) }\end{array}$ & $\begin{array}{c}\text { Proportion } \\
\text { of matched } \\
\text { areas }\end{array}$ \\
\hline Center Grande-Terre & 1296 & 1740 & $73 \%$ \\
Eastern Grande-Terre & 4034 & 5007 & $76 \%$ \\
Marie-Galante & 3114 & 4218 & $70 \%$ \\
Northern Basse-Terre & 3924 & 5035 & $76 \%$ \\
Northern Grande-Terre & 5636 & 7201 & $74 \%$ \\
Southeastern Basse-Terre & 1984 & 2999 & $56 \%$ \\
Southwestern Basse-Terre & 991 & 1150 & $74 \%$ \\
\hline Sum & 20978 & 27350 & $77 \%$ \\
\hline
\end{tabular}

Based on the farm type algorithm implemented in MOSAICA at the farm scale, we compared changes in the number of farms in the types in the original geographic database to the simulated one from the calibrated procedure (Table 4). We observed an overall good simulation level at the farm scale with approximately $81 \%$ of the farms classified in the right type. Results were good for "breeders", "specialised cane-growers" and "crop-gardeners", "banana growers" and "mixed cane-growers breeders" showing that these types of farms were correctly classified, while results were average for "diversified cane-growers", "arboriculturists", and "diversified". However, most of the misclassified farms were classified in groups that are really close to their initial type in terms of crop area. For instance, $35 \%$ of "arboriculturists" were initially classified in the "diversified" group in this simulation, and the "diversified" group is close to "arboriculturists" in term of acreage. The hypothesised level of risk aversion of farmers initially stated by the research team proved to be appropriate to reproduce the behaviour of farmers in terms of their choice of cropping system after a few iterations. At the farm level, the model provides a good-quality reproduction of current farming systems. 


\begin{tabular}{lccc}
\hline $\begin{array}{l}\text { Areas with homogeneous } \\
\text { soil and climate conditions }\end{array}$ & $\begin{array}{c}\text { Number of fields with a } \\
\text { match between the initial and } \\
\text { simulated crop }\end{array}$ & $\begin{array}{c}\text { Total number of } \\
\text { fields }\end{array}$ & $\begin{array}{c}\text { Proportion } \\
\text { of matched } \\
\text { fields }\end{array}$ \\
\hline Center Grande-Terre & 924 & 1540 & $60 \%$ \\
Eastern Grande-Terre & 2574 & 3911 & $66 \%$ \\
Marie-Galante & 3948 & 6054 & $65 \%$ \\
Northern Basse-Terre & 2645 & 4251 & $62 \%$ \\
Northern Grande-Terre & 3729 & 5269 & $71 \%$ \\
Southeastern Basse-Terre & 1875 & 3056 & $61 \%$ \\
Southwestern Basse-Terre & 724 & 976 & $74 \%$ \\
\hline Sum & 16419 & 25057 & $66 \%$ \\
\hline
\end{tabular}

422

Table 5: Results of calibration compared with the current crop areas and the number of fields

The evaluation of the model at the field scale showed that we correctly modelled the crops grown on $66 \%$ of plots, which represent $77 \%$ of the area of the territory (Table 5). This percentage can be considered satisfactory given the number of activities in the model the farmers can choose. This level of precision was homogeneous among 6 out of 7 for the sub regions but was lower for the southeastern Basse-Terre for which only $56 \%$ of areas were correctly modelled. This lower level of precision is related to the rotation of bananas and sugarcane that compose one cropping system but is allocated to several plots. 


\subsubsection{Cropping patterns changes under scenarios}

434

435 436

437

438

439

440

441

442

443

444

445

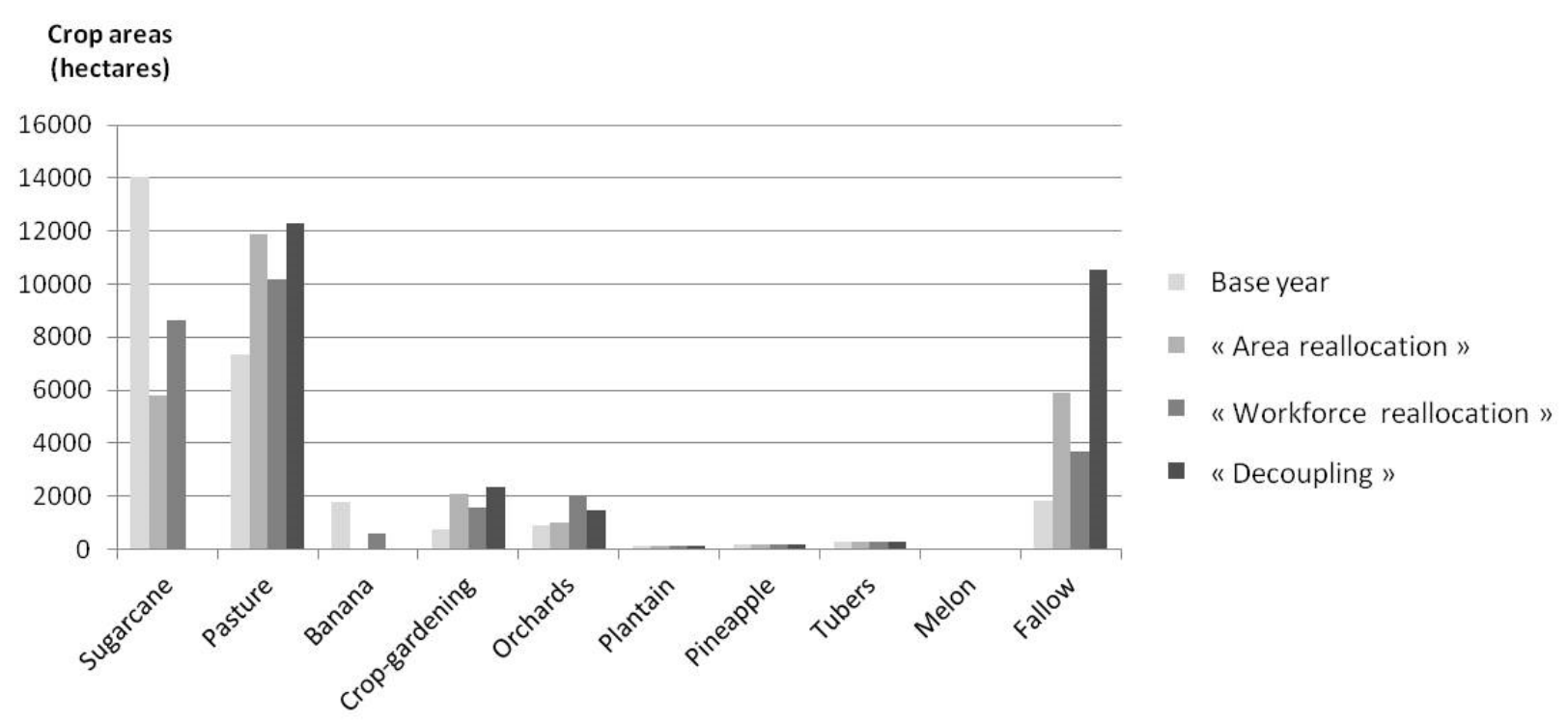

Crops in Guadeloupe

Figure 6: Acreages evolution between the base year and the three scenarios at the Guadeloupean scale

The general trends observed throughout the three scenarios demonstrate a sharp decrease in sugarcane and banana production over the island (Figure 6). By contrast, the areas devoted to pasture and fallow fields increase and the area devoted to crop gardening and orchards increase more progressively, as well.

In the "area reallocation" scenario, the sugarcane and banana area greatly decreased from 14000 hectares to less than 6000 and from close to 2000 hectares to 0 , respectively. In parallel, the pasture area increased from close to 7000 to 12000 hectares and fallow field areas increased from 2000 to close to 6000 hectares. Crop-gardening areas doubled from 900 hectares to 2000, and the orchard areas increased slightly from 1000 to 1200 .

In the "workforce reallocation" sugarcane areas decreased from 14000 to more than 8000 hectares, and the banana areas in Guadeloupe remained at 600 hectares. The increase in the pasture, fallow fields and crop-gardening areas were weaker. Pasture areas reached 10000 hectares, fallow field areas 
increased to 4000 hectares, and crop-gardening areas accounted for 1500 hectares. The orchard area

450 increased from 1000 to 2000 hectares.

451 In the "decoupling" scenario, sugarcane and banana disappeared, and the pasture area remained at the

452 same level as that for the "area reallocation" scenario, at 12000 hectares. The fallow area greatly

453 increased from an initial 2000 to more than 10000 hectares. The level reached by crop-gardening in

454 this scenario was the highest, at 2500 hectares, and the orchard areas were close to their level in the

455 "area reallocation" scenario, at 1500 hectares.

\subsubsection{Change in cropping system organisation at the sub-regional scale}

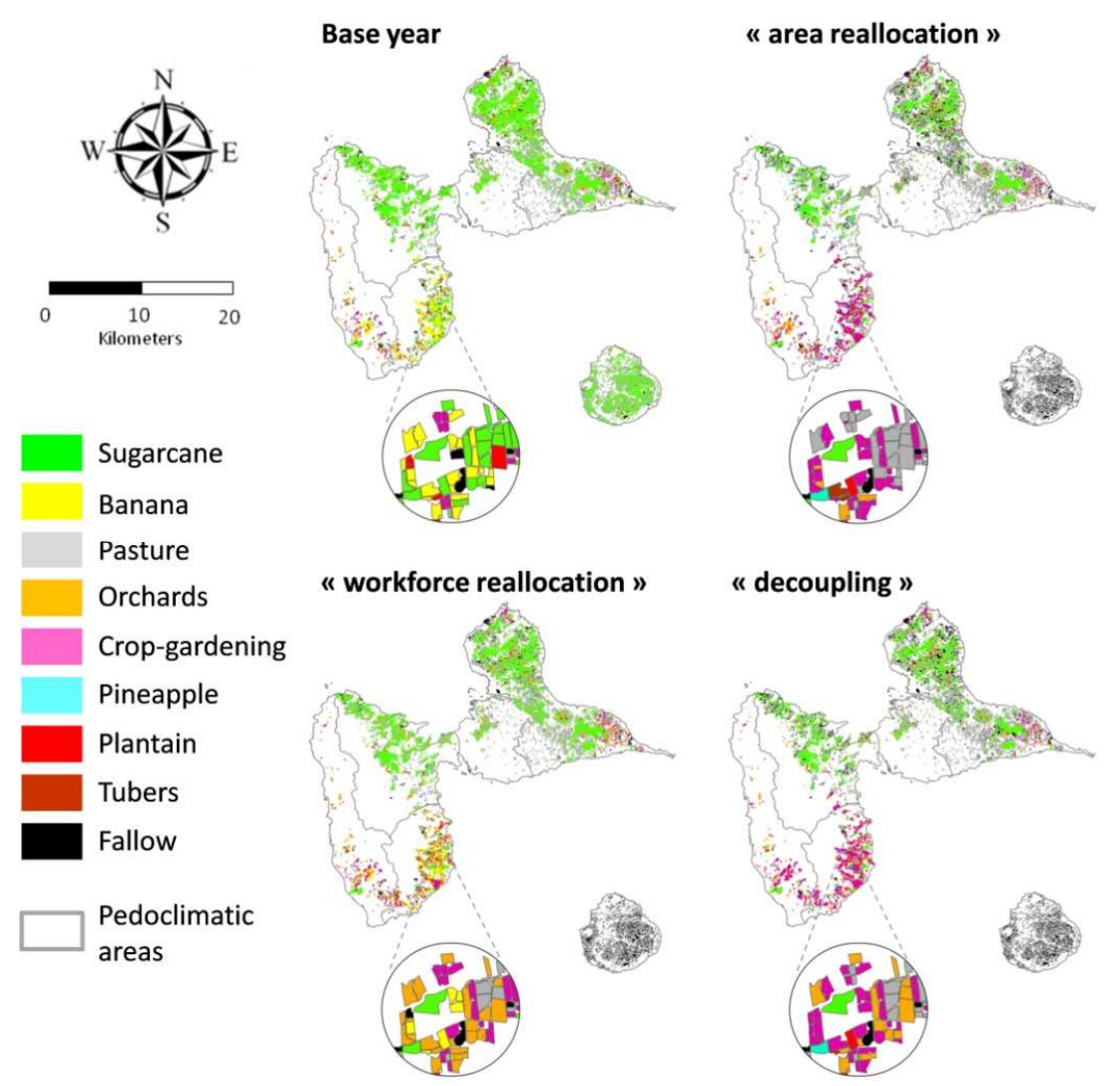

Figure 7: Cropping systems mosaics from the base year and the three scenarios

459 The new organisation of cropping systems into sub-regions is described in Figure 7.

In the three scenarios, the sugarcane in the northern and eastern Grande-Terre and Marie-Galante is largely replaced by pasture areas, especially in the "area reallocation" and "decoupling" scenarios. The 
465 and pasture instead of bananas and sugarcane, and the "workforce reallocation" scenario helped to 466 maintain the banana area.

\subsubsection{Farm type changes}

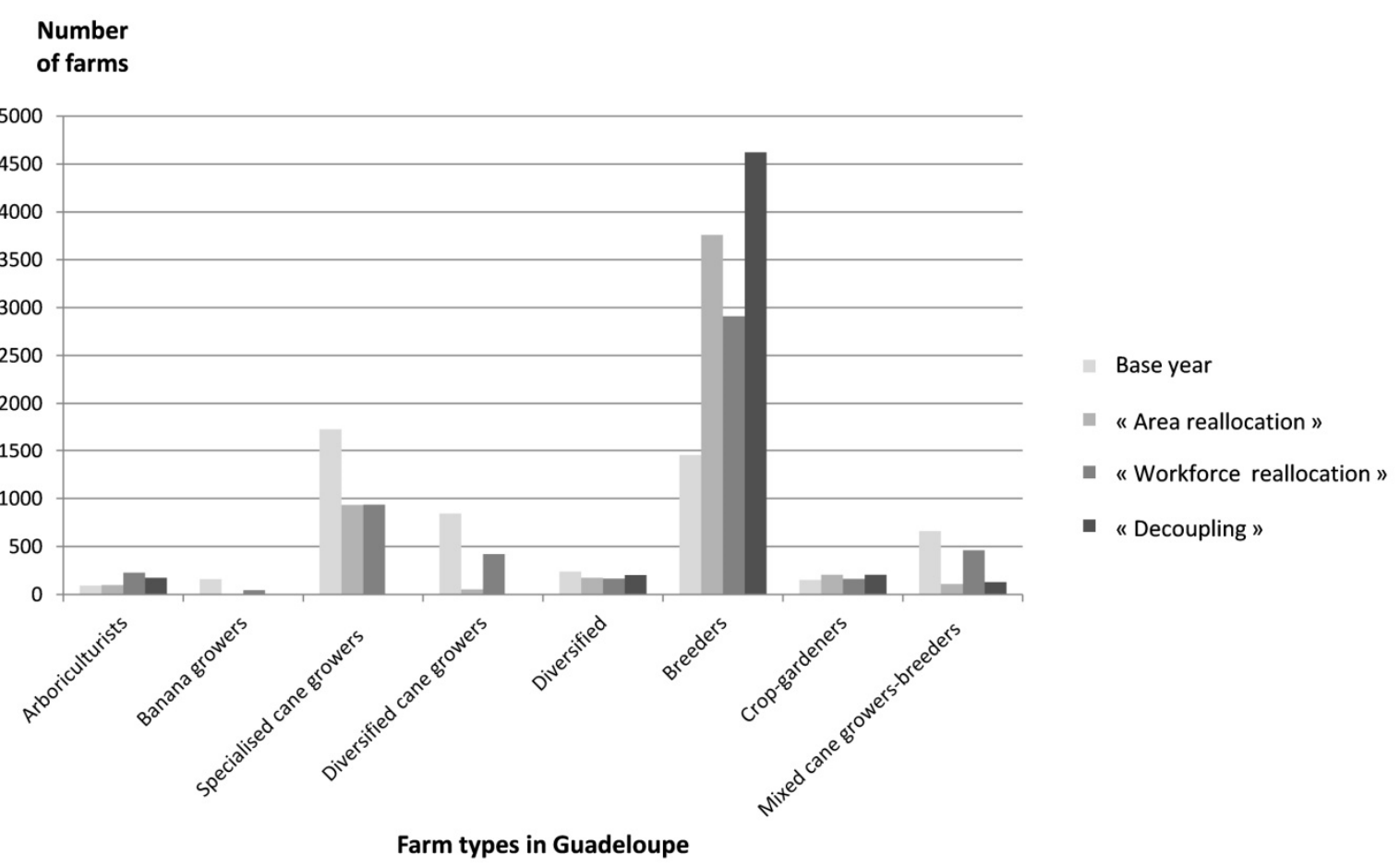

469 Figure 8: Farm types evolution between the base year and the three scenarios at the Guadeloupean 470 scale

471 The main trends in these scenarios were a decrease in "specialised cane-growers", "banana growers",

472 "mixed cane-growers breeders" and "diversified cane-growers" and, in parallel, an increase in

473 "breeders", "arboriculturists" and "crop-gardeners" (Figure 8). 


\subsubsection{Changes in sustainability levels}

\begin{tabular}{|c|c|c|c|c|c|}
\hline $\begin{array}{l}\text { Sustainability } \\
\text { objectives }\end{array}$ & Indicators & Base year & $\begin{array}{l}\text { "Area } \\
\text { reallocation" }\end{array}$ & $\begin{array}{l}\text { "Workforce } \\
\text { reallocation" }\end{array}$ & "Decoupling" \\
\hline \multirow{2}{*}{$\begin{array}{l}\text { Improving the } \\
\text { agricultural added } \\
\text { value }\end{array}$} & Overall farm revenues $\left(\mathrm{M€} . \mathrm{y}^{-1}\right)$ & 96 & 138 & 125 & 162 \\
\hline & $\begin{array}{l}\text { Repartition of the revenue among the } \\
\text { farm population }\end{array}$ & 0.65 & 0.65 & 0.74 & 0.71 \\
\hline $\begin{array}{l}\text { Increasing the } \\
\text { independence from } \\
\text { subsidies }\end{array}$ & $\begin{array}{l}\text { Total amount of subsidies } \\
\left(\mathrm{M} € \cdot \mathrm{yr}^{-1}\right)\end{array}$ & 75 & 60 & 62 & 72 \\
\hline \multirow{3}{*}{$\begin{array}{l}\text { Reaching food-self } \\
\text { sufficiency }\end{array}$} & $\begin{array}{l}\text { Ratio of produced carbohydrates } \\
\text { over needs }\end{array}$ & $15 \%$ & $20 \%$ & $22 \%$ & $22 \%$ \\
\hline & $\begin{array}{l}\text { Ratio of produced proteins over } \\
\text { needs }\end{array}$ & $22 \%$ & $28 \%$ & $27 \%$ & $29 \%$ \\
\hline & Ratio of produced fats over needs & $9 \%$ & $13 \%$ & $19 \%$ & $16 \%$ \\
\hline $\begin{array}{l}\text { Producing local } \\
\text { energy from } \\
\text { agriculture }\end{array}$ & $\begin{array}{l}\text { Energy potential produced by crops } \\
\left(\mathrm{MW} . \mathrm{yr}^{-1}\right)\end{array}$ & 33 & 16 & 24 & 0 \\
\hline $\begin{array}{l}\text { Contributing to } \\
\text { employment }\end{array}$ & Total number of workers (persons) & 3105 & 2566 & 2928 & 2772 \\
\hline $\begin{array}{l}\text { Insuring safety of } \\
\text { locally produced } \\
\text { foodstuff }\end{array}$ & $\begin{array}{l}\text { Area with a potential chlordecone } \\
\text { contamination of food crops }\end{array}$ & 1170 & 2013 & 1529 & 1843 \\
\hline $\begin{array}{l}\text { Improving the state } \\
\text { of biodiversity }\end{array}$ & $\begin{array}{l}\text { Risk for birds in high-value } \\
\text { ecological zones }\end{array}$ & 1.0 & 0.5 & 0.7 & 0.1 \\
\hline \multirow{4}{*}{$\begin{array}{l}\text { Enhancing water } \\
\text { quality }\end{array}$} & Ratio of potentially polluted rivers & $39 \%$ & $8 \%$ & $30 \%$ & $22 \%$ \\
\hline & $\begin{array}{l}\text { Ratio of potentially polluted water } \\
\text { abstraction sources }\end{array}$ & $36 \%$ & $22 \%$ & $30 \%$ & $22 \%$ \\
\hline & $\begin{array}{l}\text { Ratio of potentially polluted water } \\
\text { catchments }\end{array}$ & $30 \%$ & $12 \%$ & $20 \%$ & $11 \%$ \\
\hline & $\begin{array}{l}\text { Amount of water needed for } \\
\text { irrigation }\end{array}$ & 17.7 & 14.7 & 19.6 & 15.1 \\
\hline $\begin{array}{l}\text { Protecting soil } \\
\text { quality }\end{array}$ & $\begin{array}{l}\text { Area potentially eroded due to } \\
\text { farming practices }\end{array}$ & 33.0 & 33 & 32.7 & 31 \\
\hline $\begin{array}{l}\text { Decreasing the } \\
\text { contribution to } \\
\text { climate change }\end{array}$ & $\begin{array}{l}\text { Overall } \mathrm{CO}_{2} \text { emissions from farming } \\
\text { activities }\left(\mathrm{CO}_{2} \text { equivalent }\right)\end{array}$ & 158 & 142 & 149 & 135 \\
\hline $\begin{array}{l}\text { Improving the } \\
\text { diversity of } \\
\text { agricultural } \\
\text { landscapes }\end{array}$ & Diversity of crops across landscape & 3.0 & 3.1 & 3.4 & 2.7 \\
\hline
\end{tabular}

\section{6}

477

478

479

Table 6: Evolution of the provision of ecosystem services between the base year and the three

$$
\text { scenarios developed }
$$

We examined the values of the indicators that contributed to the sustainable development of cropping system mosaics in the three scenarios (Table 6).

In terms of economic sustainability, these three developed scenarios were relevant because they performed better than the base year in terms of economic sustainability, except for the repartition of 
the revenue among the farm population that was better for the base year. For the economic sustainability, the "area reallocation" scenario performed well with a good level of added agricultural value, at $138 \mathrm{M} € . \mathrm{yr}^{-1}$, with the lowest subsidy level of $60 \mathrm{M€} \cdot \mathrm{yr}^{-1}$. This increase in added agricultural value is related to the increase in the cultivation of crop-gardening and orchards, and the decrease in the subsidy level is related to the decrease in bananas and sugarcane.

For social sustainability, the scenarios performed better in terms of food self-sufficiency, especially scenario 3, with an increase of nearly $50 \%$ in food-self-sufficiency for each nutrient. The production of electricity among the scenarios strongly decreased from 33 MW to $0 \mathrm{MW}$ in the "decoupling" scenario because of the reduction in bagasse production from sugarcane in all scenarios. The total need for workers was 3105 people during the base year, and this need decreased in the scenarios to 2566 for "area reallocation". The risk of food crop contamination by chlordecone strongly increased in the "area reallocation" scenario to 2,566 ha and less in the "workforce reallocation" scenario and engaged in "decoupling" to reach 1,529 and 1,843 hectares respectively. This is due to the cultivation of cropgardening and tubers on chlordecone contaminated soils in the south of Basse-Terre.

In focusing on environmental sustainability, the pressure on biodiversity and water resources decreased over the three scenarios. This was especially true for the "area reallocation" scenario for which the pesticide pressure in water abstraction sources, water catchments and rivers was two times less important than the base year with $8 \%$ of rivers, $22 \%$ of water abstractions sources and $12 \%$ of water catchments. The amount of water for irrigation decreased from that in the base year in the "area reallocation" and "decoupling" scenarios by $3 \mathrm{Mm}^{3}$ and $2 \mathrm{Mm}^{3}$, respectively. In the "workforce reallocation" scenario, the water irrigation increased by $2 \mathrm{Mm}^{3}$. The $\mathrm{CO}_{2}$ emissions decreased in all scenarios from 158 to a minimum of 135 millions of $\mathrm{kg}$ of $\mathrm{CO}_{2}$ equivalents in the "decoupling" scenario. The diversity of crops increased from the base year to the "workforce reallocation" scenario from 3 to 3.4, remaining the same in the "area reallocation" scenario and decreasing in the "decoupling" scenario to 2.7 . 


\section{Discussion}

510

511

512

513

514

515

516

517

518

519

520

521

522

523

524

525

526

527

528

529

530

531

532

The primary strengths of MOSAICA are its abilities (i) to model the impacts of scenarios on the composition and organisation of the cropping system mosaics and (ii) to assess the consequences of these changes for regional sustainability issues with spatially explicit indicators.

\subsection{Model capabilities for multi-scale analysis}

The regional bioeconomic model MOSAICA has the ability to design cropping system mosaics that result from the integration of different information at multiple scales. The model integrates field, farm, sub-regional and regional information, linking it all together. The combination of changes at these different scales modifies the farmer's choice and subsequently the entire cropping systems mosaic. The modelling of farmer cropping system choices and the in fine creation of cropping system mosaics resulting from the modification of a set of rules at different spatial scales is innovative for the creation of landscape mosaics. The design of such modelling approaches at regional scale requires a large amount of data and simplification of the diversity of farming contexts, farming and cropping systems in the entire region. In bioeconomic models, this spatial scale chain has rarely been implemented because of the lack of field and farm data. Most studies either link the field scale with the farm scale (Chavez et al., 2014) or the farm scale with the regional scale (Louhichi et al., 2010; van Ittersum et al., 2008), but the field-farm-region chain with individual data has, to our knowledge, never previously been represented in an entire region in a spatially explicit way. This inter-relation of scales can help in design and assessment innovations at multiple scales and measure their impact at the regional scale to improve sustainable development of regions (Dogliotti et al., 2014). This multi-scale modelling is especially important for addressing sustainability issues, such as food security or biodiversity preservation, that require multi-scale, relevant strategies for resolution (Spiertz et al., 2012; Cunningham et al., 2013). 
The gaps revealed in the database should be taken into account while performing the scenario analysis. They are the origins of inconsistencies in the analysis of the scenario impacting cropping system changes (Schaldach and Alcamo, 2006), especially when addressing ecosystem service assessments (Hou et al., 2013).

\subsection{Spatial representation of the integrated assessment of agricultural systems}

This model allows for the ex ante assessment of new cropping system mosaics with a set of indicators that provide information on the impacts of the new cropping systems in a spatially explicit way and the trade-offs in the provision of services. For instance, in our case study, the "decoupling" scenario is very good in terms of providing added agricultural value, but the risk of crop contamination from chlordecone is higher because of the development of crop-gardening cropping system in the southeastern part of Basse-Terre, which is very polluted (Cabidoche et al., 2009). Bioeconomic models have historically been designed and applied to assess the impact of policy changes on economic, environmental and social indicators of agricultural systems, but most of these models were not spatially explicit, and the indicators were mostly calculated at the farm scale in bioeconomic farm models (Janssen and van Ittersum, 2007).

The spatially explicit assessment with the model will help decision-making in the implementation of spatial policies. Thus, in the "workforce reallocation" scenario, the amounts of intensive cropping system, crop-gardening and orchard areas are lower than they are in the "decoupling" scenario, but their environmental impacts are generally higher than in the "decoupling" scenario. This finding is the result of intensive cropping systems that are close to environmental areas in the "workforce reallocation" scenario, despite being less prevalent in the territory. The field scale allocation of cropping systems that are linked to a specific spatial location in the territory is appropriate for the ecosystem services provision issue.

The model is also able to focus on the farm scale and thus help make decision-makers become aware of the possible impact of policies on farming systems. In Guadeloupe, the test of three exploratory 
scenarios with changes in the current agricultural policy raises awareness of the great impacts that this type of change could have on the agricultural areas and the farm cropping plan. The use of farm typology is particularly useful for visualising the evolution of farms within the territory from the base year to different situations. This evolution is an indicator of the farmer cropping plan changes within the territory and provides information on the trajectories of change and the inner reorganisation of farms.

\subsection{Limits of the model in the simulation of scenarios}

Farmer's decision processes are simplified in MOSAICA and its representation could be improved with more information on farms and farmers. Farmers' attitudes towards innovation and the roles of skills, training, and investment capacity are not taken into account in the present model but could lead to differentiated responses to scenarios. Moreover, the fixed costs and the transaction costs that can decrease the gross margin of new activities at the farm scale could be included in the study if information on the farm investment is available. The possible market for land and off-farm labour could be added to the analysis to account for the changes in the size of farm and labour over time. Technical coefficients were implemented in an empirical way and do not differ between farm types or between the different biophysical conditions. In our case study, the model incorporates the average technologies and average economic performance that may strongly differ among farms. Moreover, the labour constraint was defined at farm scale, in a second version of the model this constraint could be implemented at regional scale to allow for the exchange of workers between farms.

The positive mathematical programming (PMP) approach (Howitt, 1995) or the extended variant of PMP (Kanellopoulos et al., 2010), which are used in bioeconomic models (e.g. the Farming system simulator, see Louhichi et al., 2010), could have been implemented in our model to ensure perfect calibration depending on the ex-post experiments and validation of the model predictions with these two calibrating procedures. The implementation of non-linear cost function could have produced a smoother response to our scenarios. This response would have been more representative of the 
diversity of farmer's responses to policy change. However, given the satisfactory results achieved with our calibration with risk, we consider it is sufficiently satisfactory to be used. Furthermore, thuis type of model provides accurate predictions of farmer behaviour (Arriaza et al., 2003; Lin et al., 1974).

\subsection{Generic nature of the model}

The MOSAICA model we presented in this paper is generic and can be transferred to other regions. The databases of activities in addition to the geographic database are independent from the model as in the Farming System SIMulator (FSSIM) model (Louhichi et al., 2010). Moreover, the calibration procedure can be reused because the typology of farms can be built directly from the geographic database of fields and their use in a given year by following the method of Chopin et al. (2015).

Nevertheless, the model requires some modifications before being implemented elsewhere. If new drivers of crop location are known, they can be incorporated in the model equations. A database of fields and farms, as complete as possible, should be available and representative of a clearly-delimited agricultural area to allocate the cropping systems to plots and to perform a spatially explicit assessment of the contribution of the cropping system mosaics to sustainable development. Cropping systems should be well defined in the area based -for instance- on available data or expertise. For the calibration of the model, a hypothesis concerning the risk aversion of farmers should be based on good knowledge of -or expertise on- the farming system in the area concerned to provide a satisfactory outcome for decision aid in regional planning. The indicator database is flexible and allows the switching on and off of indicators based on their relevance for the area under study.

\subsection{Possible model developments}

Despite being able to provide a possible image of the future from these exploratory predictive scenarios (Borjesön et al., 2006), decision-aid could benefit from further development of the model. For instance, MOSAICA does not reveal the transition from the base year to these possible futures. MOSAICA is static, but could be transformed into a dynamic model by characterising the inter-annual variations in cropping system externalities; for instance, the annual gross margin of perennial cropping systems is generally low in the first years after implementation and increased when full production is 
reached. This multi-annual characterization of cropping system would make it possible to take into account temporal aspects of the transition of agricultural systems from the present to future states. The bioeconomic model could be linked to other modelling tools that account for market and sector-level changes. These models could simulate increases in farm area or the disappearance of farms due, for instance, to insufficient revenues. Moreover, to allow higher variability in the performance of cropping system at the different locations in a given region, MOSAICA could be coupled to crop models adapted to the different soil and climate conditions, or fed with the results of crop models in order to obtain differentiated performances of the cropping system depending on the local biophysical conditions of the fields in question (Djanibekov et al., 2013). Furthermore, marginally developed livestock production could have been introduced since it could benefit from agricultural policies and then become a more important activity at the farm and regional scale. Adding new activities to the database could be useful to test whether or not these systems would have positive impacts at the regional scale and under which conditions they could be implemented by farmers. These additions could better reproduce possible changes in the cropping system mosaic and hence provide more precise information for decision-makers and stakeholders.

\section{Acknowledgements}

The authors wish to thank the Agrigua association, the National Institute of Geographic and Forest Information (IGN), the Guadeloupe Department of public works, land use and housing (DEAL), the Regional Agency for Health (ARS), and the Guadeloupe Chambers of Agriculture (CA) for providing the geographic information used in this study. We would like to thank all the experts from the different agricultural institutes in Guadeloupe, and Regis Tournebize, for their help with data collection and their expertise on the activities and equations defined in this paper. We also thank the two anonymous reviewers for their helpful comments on the first version of the manuscript. The first author benefited from a PhD grant co-financed by the European Union (Fonds Social Européen), Guadeloupe Regional 
642

643

644

645

646

647

648

649

650

651

652

653

654

655

656

657

$\mathrm{n}^{\circ}$ 1/1.4/-33634 - Projet Recherche Biomasse Energie Canne à CApesterre Phase 2 (REBECCA).

Authors would like to deeply thank Dr. Yves-Marie Cabidoche, who passed away in June 2012, and to dedicate this article to him.

\section{Appendix}

If $A_{p} \leq \operatorname{Amin}_{a}$,

$X_{a, p}=0$ for activities" mechanized sugarcane" (A is the field area). No harvest possible under 0.3ha by harvest operator

If Alt $_{p} \geq$ Alt $\max _{a}$

$X_{a, p}=0$ for activities "mechanized sugarcane" no access above 250 meters

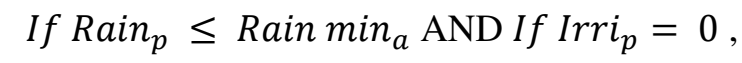

$X_{a, p}=0 ;$ Rain min is determined based on crop water needs; Irri is the access to irrigation ( $0:$ no access/1: access to irrigation due to presence in irrigation schemes);

If Soil $_{p}=2$

$X_{\text {pineapple,p }}=0$, Soilp is soil type of field $p$ and 2 is the value attributed to calcic soils for pineapple based activities.

658 If $L t_{p}=1$ 
659

660

661

662

663

664

665

666

667

668

669

$$
\left(\sum_{p} X_{a, p}\right) \leq \operatorname{Rot}_{a} *\left(\sum_{p} \text { Xinit }_{a, p}\right)
$$

Land ressource constraint at farm scale

670

671

672

673

$$
\left(\sum_{p} X_{b a n, p} * Y_{b a n}\right) \leq\left(\sum_{p} X_{\text {init }} \text { ban }, p * Y_{b a n}\right)
$$

674 where $X_{\text {ban }}$ is the area of banana. pineapple and 0.5 for tubers.

where $X_{a}$ is here either pineapple or tubers and Rot value is the return frequency which is 0.33 for

675

676 If $I G P_{p}=0$,

$677 X_{\text {melon, } p}=0, I G P_{p}$ is the location or no of field $p$ in protected geographic indication area for melon 678 production. 


\section{References}

Acs, S., Berentsen, P., Huirne, R., van Asseldonk, M., 2009. Effect of yield and price risk on conversion from conventional to organic farming. Australian Journal of Agricultural and Resource Economics . 53, 393-411. doi: 10.1111/j.1467-8489.2009.00458.x.

Agreste, 2010. Recensement agricole 2010. Premières tendances. №270. Novembre 2011. http://agreste.agriculture.gouv.fr/IMG/pdf_D97111A02.pdf. Accessed 21 March 2014.

Andersen, E., Elbersen, B., Godeschalk, F., Verhoog, D., 2007. Farm management indicators and farm typologies as a basis for assessments in a changing policy environment. Journal of Environmental Management 82, 353-362. doi:10.1016/j.jenvman.2006.04.021.

Arriaza, M., Gomez-Limon, J.A., 2003. Comparative performance of selected mathematical programming models. Agricultural Systems 77, 155-171. doi:10.1016/S0308-521X(02)00107-5.

Aubry, C., Papy, F., Capillon, A., 1998. Modelling decision-making processes for annual crop management. Agricultural systems, 56(1), 45-65. doi:10.1016/s0308-521x(97)00034-6.

Bechini, L., Castoldi, N., 2009. On-farm monitoring of economic and environmental performances of cropping systems: Results of a 2-year study at the field scale in northern Italy. Ecological Indicators 9, 1096-1113. 
Belhouchette, H., Louhichi, K., Therond, O., Mouratiadou, I., Wery, J., Ittersum, M.v., Flichman, G., 2011. Assessing the impact of the Nitrate Directive on farming systems using a bio-economic modelling chain. Agricultural Systems 104, 135-145. doi:10.1016/j.agsy.2010.09.003.

Bergez, J.-E., Garcia, F., Leenhardt, D., Maton, L., Castelletti, A., Sessa, R.S., 2007. Chapter 7 Optimising irrigation management at the plot scale to participate at the regional scale water resource management. Topics on System Analysis and Integrated Water Resources Management. Elsevier, Oxford, 141-160. doi: 10.1016/B978-008044967-8/50007-5.

Blazy, J.-M., Ozier-Lafontaine, H., Dore, T., Thomas, A., Wery, J., 2009. A methodological framework that accounts for farm diversity in the prototyping of crop management systems. Application to banana-based systems in Guadeloupe. Agricultural Systems 101. 30-41. doi: 10.1016/j.agsy.2009.02.004.

Börjeson, L., Höjer, M., Dreborg, K.-H., Ekvall, T., Finnveden, G., 2006. Scenario types and techniques: Towards a user's guide. Futures 38, 723-739. doi:10.1016/j.futures.2005.12.002.

Bureau, J.C., Guyomard, H., Requillart, V., 2001. On inefficiencies in the European sugar regime. Journal of Policy Modeling 23, 659-667. doi:10.1016/S0161-8938(01)00080-1.

Cabidoche, Y-M., Achard, R., Cattan, P., Clermont-Dauphin, C., Massat, F., Sansoulet, J., 2009. Long-term pollution by chlordecone of tropical volcanic soils in the French West Indies: A simple leaching model accounts for current residue. Environmental Pollution 157, 1697-1705. doi: 10.1016/j.envpol.2008.12.015. 
727 Cabidoche, Y.M., Lesueur-Jannoyer, M., 2012. Contamination of Harvested Organs in Root Crops

728 Grown on Chlordecone-Polluted Soils. Pedosphere 22, 562-571. doi:10.1016/S1002-0160(12)60041-1.

729

730

731

732

733

734

735

736

737

738

739

740

741

742

743

744

745

746

747

748

Ceriani, L., Verme, P., 2012. The origins of the Gini index: extracts from Variabilità e Mutabilità (1912) by Corrado Gini. The Journal of Economic Inequality 10, 421-443. doi: 10.1007/s10888-0119188-X.

Chavez, M.D., Berentsen, P.B.M., Oude Lansink, A.G.J.M., 2014. Analyzing diversification possibilities on specialized tobacco farms in Argentina using a bio-economic farm model. pp. 35-43. doi:10.1016/j.agsy.2014.03.009.

Chopin, P., Blazy, J.-M., 2013. Assessment of regional variability in crop yields with spatial autocorrelation: Banana farms and policy implications in Martinique. Agriculture, Ecosystems \& Environment 181, 12-21. doi:10.1016/j.agee.2013.09.001.

Chopin, P., Blazy, J.-M., Doré, T., 2015. A new method to assess farming system evolution at the landscape scale. Agronomy for Sustainable Development 35, 325-337. doi: 10.1007/s13593-0140250-5.

Chopin, P., Blazy, J.-M., Doré, T., Guindé, L.,. Contribution of agricultural landscapes to the sustainable development of territories: Application to Guadeloupe. Submitted to European Journal of Agronomy. 
750 Clostre, F., Letourmy, P., Lesueur-Jannoyer, M., 2015. Organochlorine (chlordecone) uptake by root vegetables. Chemosphere 118, 96-102.

752

CTCS (Centre technique Interprofessionnel de la canne à sucre de la Guadeloupe), 2005. Manuel technique de la canne à sucre. http://www.ctcs-gp.com/. Accessed 04 October 2013.

Cunningham, S.A., Attwood, S.J., Bawa, K.S., Benton, T.G., Broadhurst, L.M., Didham, R.K.,

McIntyre, S., Perfecto, I., Samways, M.J., Tscharntke, T., Vandermeer, J., Villard, M.-A., Young,

A.G., Lindenmayer, D.B., 2013. To close the yield-gap while saving biodiversity will require multiple doi:10.1016/j.agee.2013.04.007.

Colmet-Daage ,F., Bernard, Z., Gautheyrou, J., Gautheyrou, M., Lagache, F., de Crecy, J., Poumaroux, A., Pallud, A., 1969. Carte des sols de la Martinique. BSA, ORSTOM, Pointe-à-Pitre. modeling approaches. Journal of Environmental Management 129, 493-502. doi:10.1016/j.jenvman.2013.08.001.

Djanibekov, N., Sommer, R., Djanibekov, U., 2013. Evaluation of effects of cotton policy changes on land and water use in Uzbekistan: Application of a bio-economic farm model at the level of a water users association. Agricultural Systems 118, 1-13. doi:10.1016/j.agsy.2013.02.004. 
773 Dogliotti, S., van Ittersum, M.K., Rossing, W.A.H., 2005. A method for exploring sustainable 774 development options at farm scale: a case study for vegetable farms in South Uruguay. Agricultural 775 Systems 86, 29-51. doi:10.1016/j.agsy.2004.08.002

776

777

778

779

780

781

782

783

784

785

786

787

788

789

790

791

792

793

Dogliotti, S., Rodriguez, D., Lopez-Ridaura, S., Tittonell, P., Rossing, W.A.H., 2014. Designing sustainable agricultural production systems for a changing world: Methods and applications. Agricultural Systems 126, 1-2. doi:10.1016/j.agsy.2014.02.003.

Dury, J., Schaller, N., Garcia, F., Reynaud, A., Bergez, J.E., 2011. Models to support cropping plan and crop rotation decisions. A review. Agronomy for Sustainable Development 32, 567-580. doi:10.1007/s13593-011-0037-x.

ESRI (Environmental Systems Research Institute), 2009. ArcGIS 9.3.1. Environmental Systems Research Institute, Redlands, California, USA.

European Union, 2012. Règlement (UE) No 1308/2013. Du parlement européen et du conseil du 17 décembre 2013 portant organisation commune des marchés des produits agricoles et abrogeant les règlements (CEE) no 922/72, (CEE) no 234/79, (CE) no 1037/2001 et (CE) no 1234/2007 du Conseil. http://eur-lex.europa.eu/LexUriServ/LexUriServ.do?uri=OJ:L:2013:347:0671:0854:fr:PDF. Accessed 24 September 2014. 
Flichman, 2002. Economic models for Assessing Sustainability of Agricultural Trade

liberalisation, 2002, SIAP Workshop: Methodological Tools for Assessing the Sustainability Impact of The EU's Economic Policies, with Applications to Trade Liberalisation Policies, Cepii.

Flichman, G.,, 2011. Bio-Economic Models applied to Agricultural Systems. Springer. doi: Environment 120, 58-69.

804 Agriculture. Macmillan Publishing Company, New York.

Hou, Y., Burkhard, B., Müller, F., 2013. Uncertainties in landscape analysis and ecosystem service assessment. Journal of Environmental Management 127, Supplement, S117-S131. doi:10.1016/j.jenvman.2012.12.002. 77, 329-342. doi: 10.2307/1243543. 
Janssen, S., van Ittersum, M.K., 2007. Assessing farm innovations and responses to policies: A review of bio-economic farm models. Agricultural Systems 94, 622-636. doi:10.1016/j.agsy.2007.03.001.

Kanellopoulos, A., Berentsen, P., Heckelei, T., Van Ittersum, M., Lansink, A.O., 2010. Assessing the Forecasting Performance of a Generic Bio-Economic Farm Model Calibrated With Two Different PMP Variants. Journal of Agricultural Economics 61, 274-294.

Laborte, A.G., Van Ittersum, M.K., Van den Berg, M.M., 2007. Multi-scale analysis of agricultural development: A modelling approach for Ilocos Norte, Philippines. Agricultural Systems 94, 862-873. doi:10.1016/j.agsy.2006.11.011.

Leenhardt, D., Angevin, F., Biarnes, A., Colbach, N., Mignolet, C., 2010. Describing and locating cropping systems on a regional scale. A review. Agronomy for Sustainable Development 30, 131-138. doi:10.1051/agro/2009002.

Leite, J.G.D.B., Silva, J.V., van Ittersum, M.K., 2014. Integrated assessment of biodiesel policies aimed at family farms in Brazil. Agricultural Systems, 64-76. doi:10.1016/j.agsy.2014.08.004.

Lin, W., Dean, G.W., Moore, C.V., 1974. An empirical test of utility vs. profit maximization in agricultural production. American Journal of Agricultural Economics 56, 497-508.

Louhichi, K., Kanellopoulos, A., Janssen, S., Flichman, G., Blanco, M., Hengsdijk, H., Heckelei, T., Berentsen, P., Lansink, A.O., Ittersum, M.V., 2010. FSSIM, a bio-economic farm model for 
840 simulating the response of EU farming systems to agricultural and environmental policies.Agricultural 841 Systems 103, 585-597. doi:10.1016/j.agsy.2010.06.006.

843 Mosnier, C., Ridier, A., Képhaliacos, C., Carpy-Goulard, F., 2009. Economic and environmental 844 impact of the CAP mid-term review on arable crop farming in South-western France. Ecological 845 Economics 68, 1408-1416.

847 Multigner, L., Kadhel, P., Rouget, F., Blanchet, P., Cordier, S., 2015. Chlordecone exposure and 848 adverse effects in French West Indies populations. Environmental Science and Pollution Research, 18496

PDRG, 2011. Programme de. Développement Rural de la. Guadeloupe. TOME 1. Données generals. V4-Tome 1-etat des lieux et stratégie-sept2011. 1/76. http://agriculture.gouv.fr/IMG/ pdf/PDRG_V4_Tome1.pdf the 24/06/2014. Accessed 24 December 2014.

POSEI France, 2012. Programme portant sur les mesures spécifiques dans le domaine de l'agriculture en faveur des régions ultrapériphériques. Tome 1. Chapitre 1 à 3. Version 2012 applicable à partir du 01 janvier 2012. Décision d'exécution C(2012) 115 du 20 janvier 2012. http://www.odeadom.fr/wpcontent/uploads/2012/03/posei-france-2012_vf_toustomes.pdf. Accessed 17 September 2014.

Ronfort, C., Souchere, V., Martin, P., Sebillotte, C., Castellazzi, M.S., Barbottin, A., Meynard, J.M., Laignel, B., 2011. Methodology for land use change scenario assessment for runoff impacts: A case study in a north-western European Loess belt region (Pays de Caux, France). Catena 86, 36-48. doi: 10.1016/j.catena.2011.02.004. 
865 Rusch, A., Valantin-Morison, M., Roger-Estrade, J., Sarthou, J-P., 2012. Using landscape indicators to 866 predict high pest infestations and successful natural pest control at the regional scale. Landscape and 867 Urban Planning 105, 62-73. doi: 10.1016/j.landurbplan.2011.11.021.

868

Simpson, E.H., 1949. Measurement of diversity. Nature 163, 688. doi:10.1038/163688a0.

870

871 Schaldach, R., Alcamo, J., 2006. Coupled simulation of regional land use change and soil carbon

872 sequestration: A case study for the state of Hesse in Germany. Environmental Modelling \& Software

873 21, 1430-1446. doi:10.1016/j.envsoft.2005.07.005.

874

875 Schipper, R.A., Bouman, B.A.M., Jansen H.G.P, Hengsdijk, H., Nieuwenhuyse, A., 2000. Integrated 876 biophysical and socio-economic analysis of regional land use. In Bouman et al. 2000, 115-44.

878 Schipper, R.A., Jansen, H.G.P., Bouman, B.A.M., Hengsdijk, H., Nieuwenhuyse, A., Saenz, F., 2001. 879 Integrated bioeconomic land-use models: an analysis of policy issues in the Atlantic Zone of Costa 880 Rica. In: Lee, D.R., Barrett, C.B. (Eds.), Tradeoffs or Synergies? Agricultural Intensification, 881 Economic Development and the Environment. CAB International, pp. 267-284. 

Pons, Y., Gaucherel, C., Viaud, V., Baudry, J., 2009. The contribution of crop-rotation organization in farms to crop-mosaic patterning at local landscape scales. Agriculture, Ecosystems \& Environment 131, 207-219. doi:10.1016/j.agee.2009.01.015.

Tillieut O., Cabidoche Y.-M., 2006. Cartographie de la pollution des sols de Guadeloupe par la chlordécone : Rapport technique. DAAF-SA \& INRA-ASTRO, Abymes, 23p.

Tixier, P., Malézieux, E., Dorel, M., Bockstaller, C., Girardin, P., 2007. Rpest:An indicator linked to a crop model to assess the dynamics of the risk of pesticide water pollution: Application to bananabased cropping systems. European Journal of Agronomy 26, 71-81.

van Ittersum, M.K., Ewert, F., Heckelei, T., Wery, J., Alkan Olsson, J., Andersen, E.,Bezlepkina, I., Brouwer, F., Donatelli, M., Flichman, G., Olsson, L., Rizzoli, A.E.,van der Wal, T., Wien, J.E., Wolf, J., 2008. Integrated assessment of agricultural systems - a component-based framework for the European Union (SEAMLESS). Agricultural Systems 96, 150-165. doi:10.1016/j.agsy.2007.07.009.

Viaggi, D., Raggi, M., Gomez y Paloma, S., Farm-household investment behaviour and the CAP decoupling: Methodological issues in assessing policy impacts. Journal of Policy Modeling 33, 127145. 
Economic indicators:

910

911

912

913

914

915

916

917

918

919

920

921

922

923

924

925

926

927

- The overall farm revenue is calculated through an aggregation of gross margins for cropping systems.

- The repartition of revenue among the farm population is the Gini indicator, and it measures equity in the repartition of farm revenue (Ceriani and Verme, 2012).

- The total amount of subsidies is the aggregation of every subsidy provided to farmers for agricultural production.

Social indicators:

- Three ratios of food nutrients produced over needs (proteins, carbohydrates and lipids) are calculated based on the nutrient contents of each crop, and the needs are calculated for the total population in Guadeloupe and the average person's needs.

- The energy potential produced by crops measures the energy that can be produced from crop or crop residues, primarily bagasse from sugarcane cultivation.

- The total number of workers is the aggregate workforce need from each cropping system.

- The area with a potential chlordecone contamination of food crops measures the area with crop contamination risk from chlordecone, a soil pollutant from former pesticide applications in banana fields; this risk considers the soil type, the crop and the level of pollution (see Clostre et al., 2015).

Environmental indicators:

Most environmental indicators are spatially explicit.

- The risk for birds in high-value ecological zones is the mean quantity of toxicity in the fields located in ZNIEFF areas (bird protection areas in Guadeloupe) depends on the level of toxicity of pesticides in cropping systems within ZNIEFF areas with the load index (Bechini and Castoldi, 2009).

- The ratios of potentially polluted rivers, water abstraction sources and water catchments are based on the intensity of cropping systems within a buffer area for rivers and within perimeters for water catchments and abstraction sources. It is calculated through an aggregation of the R-pest indicator at the cropping system scale (Tixier et al., 2007).

- The amount of water needed for irrigation is based on crop needs and mean rainfalls in the area on a monthly basis. For each month, the water need is calculated, and all the needs from each field and each period are aggregated for fields located in the irrigation perimeters.

- The area potentially eroded due to farming practices depends on the soil type, the slope and the soil cover by crops. 
- The overall $\mathrm{CO}_{2}$ emissions from farming practices is not spatially explicit and only represents the aggregation of $\mathrm{CO}_{2}$ emissions from the farm to the region based on the emissions of cropping system and grazing livestock inputs from the cradle to the farm gate.

- The diversity of crops across the landscape is based on the Inverse Simpson's Diversity index, which calculates the diversity of crops in each sub-region and the mean level of diversity at the Guadeloupe scale (Simpson, 1949).

\section{$\underline{\left.2^{\circ}\right) \text { Details on the current policies: }}$}

- POSEI arrangements are subsidies that account for the geographic and economic handicaps of the Outermost Regions, their remoteness, insularity, small size, topography and climate and their economic dependence on a few products (POSEI France, 2012). POSEI measures are funded under the first pillar of the Common Agricultural Policy, and they fall into two categories, that is, the specific supply arrangement and measures to support local agricultural production.

- For sugarcane, the POSEI provides a subsidy to the sugar companies and a transportation subsidy to the farmers. The subsidy provided to the industry is 14 $\mathrm{M} € . \mathrm{yr}^{-1}$, and this amount is used to increase the sugarcane payment to farmers from $14.22 €$. ton $^{-1}$ to $32.34 €$.ton ${ }^{-1}$ on average with a subsidy of $18.12 €$. ton $^{-1}$ depending on the saccharine richness of the sugarcane in the sub-regions. The other subsidy is used for helping farmers to pay for the sugarcane transport from the farmer's fields to the nearest collective point. This amount depends on the area in which the field is located and varies from $2.75 €$.ton ${ }^{-1}$ in the eastern Grande-Terre, the northern Basse-Terre and Marie-Galante, to $3.23 €$. ton $^{-1}$ in the centre of Grande-Terre, and $4.76 €$. ton $^{-1}$ in other areas.

- For banana production, the POSEI provides a protection subsidy of $400 €$. ton $^{-1}$ that is based on an historic production quota that was allocated to banana farms. This subsidy is provided at the farm scale, but its amount depends on the banana production of farms compared with the farm historical reference of banana production. An $80 \%$ production of the farm's historical reference ensures $100 \%$ subsidies, and below $80 \%$, the decrease in production decreases the amount of subsidies proportionally. This subsidy can then be compared with a payment coupled to production.

- The rural development program of Guadeloupe (PDRG) is financed by the European Union and national subsidies that are provided for agri-environmental measures, the replanting of sugarcane, fallowing and production in less favoured areas. These agri-environmental measures are also compensatory measures of the yield reductions that result from applying a set of management practices aimed at protecting the environment. Payments for bananas were approximately $658 €$. ha $^{-1}$ for banana farms when using fallow fields in their rotation to manage the population of nematodes, and $82 € \cdot \mathrm{ha}^{-1}$ was provided for harvesting the sugarcane without burning it because of the loss of leaves for soil protection. Payments for orchards, crop-gardening, plantains, and pineapples are not provided (PDRG, 2011). The rural development program also provides a subsidy for the replanting of sugarcane fields for the 
duration of the sugarcane plantation. This amount is $900 € . \mathrm{ha}^{-1}$ for seven years on average. Compensatory payments for Guadeloupean farms located in mountainous areas are not integrated into the amount of subsidies when currently considering the small number of farmers that received this subsidy, or approximately 50, in 2010.

- National subsidies are provided for sugarcane cultivation as a transition payment coupled to production after the reform of the sugar Common Market Organization in 2007. Its value varies depending on the level of saccharine richness but is on average $23.81 €$.ton $^{-1}$ of sugarcane (CTCS, 2005).

- Sugarcane farmers are also remunerated for providing bagasse, a residue from sugarcane pressing, for electricity production. The amount of this payment is $10 €$.ton ${ }^{-1}$ of sugarcane and is not provided for the farmers in Marie-Galante who use the bagasse is directly in the sugar factory instead of selling it to a power plant, as in Grande-Terre and Basse-Terre. 